\title{
押抜きせん断破壊するスラブ状RC構造物の 非線形三次元有限要素法解析
}

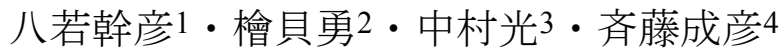

1正会員（株）錢高組 東京支社 土木支店（テ102-8678 東京都千代田区一番町31）

E-mail: yawaka_mikihiko@zenitaka.co.jp

2正会員 山梨大学大学院教授 医学工学総合研究部（广 400-8511 山梨県甲府市武田四丁目3-11）

3正会員 名古屋大学大学院教授 工学研究科社会基盤工学専攻（率464-8603 名古屋市千種区不老町）

${ }^{4}$ 正会員 山梨大学大学院助教授 医学工学総合研究部（广400-8511 山梨県甲府市武田四丁目3-11）

本研究は, スラブ状RC構造物の押抜きせん断破壊性状に対して我々が提案する非線形三次元有限要素 法の適用性を検討したものである.

これまで, RC構造物の押抜きせん断破壊耐力算定に関する解析的な研究は少なく, 主として経験的な アプローチが数多くなされてきたが, 本研究では, 載荷位置を変化させた薄いRCスラブおよび, フーチ ングのようなやや厚みのあるスラブや曲げモーメントを受ける柱付きフーチングの押抜きせん断実験結果 とFEM解析結果の比較検討を行った。 その結果, 著者らが開発した解析方法によって, 耐荷力, 斜めひび 割れ性状および, 荷重一変位関係において実験結果を概袓えられる事が示された。

Key Words : punching shear failure, load-carring capacity, crack pattern, nonlinear 3D-FEM

\section{1.はじめに}

既往の土木構造物は鉄筋コンクリートで建造され ているものも多く, 特にエネルギー関連施設や, 重 要公共施設に利用される例が少なくない，そのため コンクリート構造物の耐荷力, 破壊性状, 変形性能 等の詳細な検証は非常に重要な問題である。しかし， コンクリート構造物の大型化に伴う寸法効果の影響 や，複雑化に伴う境界条件の不明確化の影響などに より, 模型実験を行って構造物の性能を確認するこ とが困難な場合も多くなっている。したがって，コ ンクリート構造物の破壊性状を精度良く予測できる 解析手法の確立が必要となる.

近年では鉄筋コンクリート部材の諸性状の解明に 有限要素法が広く用いられ, 二次元有限要素法を用 いることにより RC はりのせん断破壊といった，局 所的かつ脆性的な破壊に対しても解析による評価が 可能となるなど, 解析技術の発展に伴い, 解析精度 の向上，適用範囲の拡大がなされてきた。

しかしながら，三次元問題であるスラブの押抜き せん断破壊への有限要素法の適用を検討した例 ${ }^{11}$ は 少ないのが現状であり, 主として経験的な方法 ${ }^{2)}$
よって耐荷力を算定しようとする研究が行われてき た. そこで本研究では, 非線形三次元有限要素法を 用いて，押抜きせん断破壊性状を解析的に評価する ことを試みた。

ここで問題となってくるのが，使用する解析モデ ルである. 三次元解析には三軸応力下におけるコン クリートの構成則を用いるのが妥当な手法だと考え られるが，三軸応力下におけるコンクリート材料の 挙動は未だ十分に解明されたとは言えず, 解析手法 の確立の妨げとなっている. 提案する解析手法 $\left.{ }^{3)}, 4\right)$ では, 三軸応力下でのコンクリートの構成則として, 一軸応力下での構成則を単純に三方向に適用すると いう，極めて簡便なモデルを使用していることが特 徵である.

本研究で, 押抜きせん断破壊性状を解析するにあ たり対象としたものは, 載荷位置をスラブ中央部か ら自由縁に近づけた場合と, 支点に近づけた場合の 薄いRCスラブ，および，鉄筋量や厚さを変えたフ ーチングのような厚みのあるRCスラブと, モーメ ントが作用する柱付きフーチングの押抜きせん断破 壊であって, 実験結果と解析結果の比較を行うこと により, 解析手法の妥当性を検討した. 


\section{2. 非線形三次元有限要素法}

\section{（1）非線形三次元有限要素法の概要}

本解析に用いた有限要素は，8節点のアイソパラ メトリック 6 面体 1 次要素で, 数值積分に用いる Gauss 点の数は 8 である. 鉄筋には, その剛性を要 素中に平均化して取り扱う RC 要素を用いた. ポス トピーク領域までの挙動を捉えるため, 変位制御の 増分解析を行い, 収束計算には Newton-Raphson 法 を用いた。

\section{（2）主応カー主ひずみ関係}

本解析では， 3 方向の主応力一主ひずみ関係とし てそれぞれ一軸応力下での構成則を用いた。従って， 三軸応力下での破壊基準などは特に考慮していない.

一軸応力下での構成則は，既往のモデルを使用し ているが, 引張破壊エネルギー $\left(G_{f t}\right)$ および, Nakamura・Higai ${ }^{5)}$ の研究結果による圧縮破壊エネル ギー $\left(G_{f_{c}}\right)$ を適用している点に特徽がある.

\section{a）圧縮応力を受けるコンクリート}

圧縮応力下のコンクリートの応力ーひずみ関係は, 図-1 に示すように最大応力 $\left(f^{\prime}{ }_{c}\right)$ までを二次放物線 (式 (1)) とし，その後応力が直線的に零まで減少 するモデルを用いた。

$$
\begin{array}{r}
\sigma_{c}=f_{c}^{\prime}\left\{2\left(\frac{\varepsilon_{c}}{\varepsilon_{0}}\right)-\left(\frac{\varepsilon_{c}}{\varepsilon_{0}}\right)^{2}\right\} \\
\text { ただし, } \varepsilon_{0}=0.002
\end{array}
$$

ここで, 応力零時のひずみ $\left(\varepsilon_{m}\right)$ は圧縮破壊エネル ギー $\left(G_{f c}\right)$ を考慮して式 $(2)$ により決定した。

$$
\begin{aligned}
& \varepsilon_{m}=\frac{G_{f c}}{f_{c}^{\prime} l_{e q}}+\frac{\varepsilon_{0}}{2} \\
& G_{f c}= 8.8 \sqrt{f_{c}^{\prime}} \quad(\mathrm{MPa} \cdot \mathrm{mm}) \\
& l_{e q}: \quad \text { 要素の等価長さ }
\end{aligned}
$$

なお，基本的には一軸応力下での構成則を用いて いるのであるが, 直交方向の引張ひずみ $\left(\varepsilon_{t}\right)$ の存在 によって圧縮強度が低下するCollins・Mitchell ${ }^{6)}$ のモ デル（式(4)）は使用している.

$$
\sigma_{2 \max }=f_{c}^{\prime} \frac{1}{0.8+0.34\left(\frac{\varepsilon_{t}}{\varepsilon_{0}}\right)} \leq f_{c}^{\prime}
$$

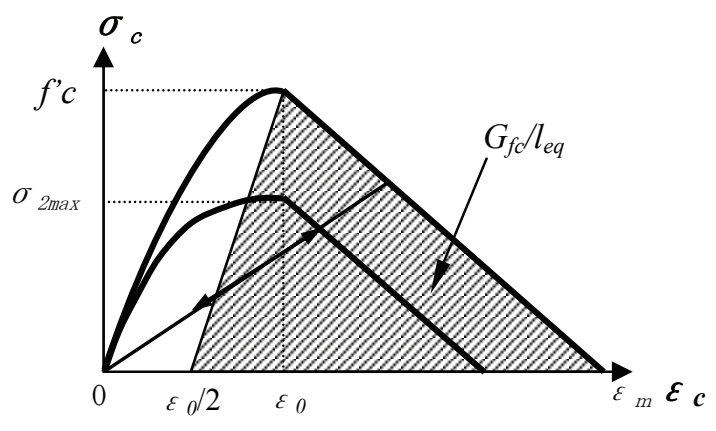

図-1 圧縮応力ーひずみ関係

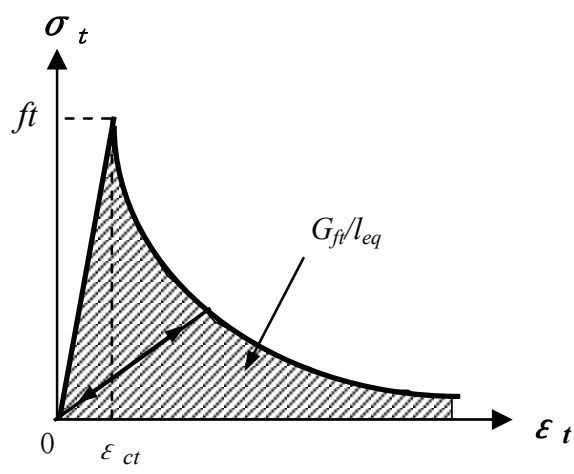

図-2 引張応力ーひずみ関係

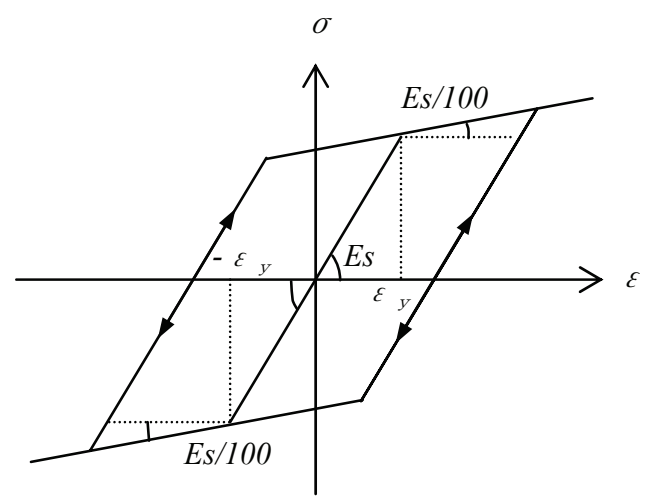

図－3 鉄筋の応力ーひずみ関係

b）引張応力を受けるコンクリート

引張応力下でのコンクリートの挙動は, 引張強度 $\left(f_{t}\right)$ までは, 直線的に応力が増加するとし, 軟化 域については, コンクリートの引張応力 $\left(\sigma_{t}\right) \sim ひ$ び割れ幅 $(w)$ 関係および引張破壊エネルギー $\left(G_{f t}\right)$ を用いて式(6)のように定めた（図-2）.

ここで, 引張応力〜ひび割れ幅関係は，-3 乗モデ ルを使用した。

$$
\begin{aligned}
& f_{t}=0.269 f_{c}{ }^{2 / 3} \\
& \sigma_{t}=f_{t}\left\{1+0.5 \frac{f_{t}}{G_{f t}} w\right\}^{-3}
\end{aligned}
$$




$$
\begin{aligned}
& w=l_{e q}\left(\varepsilon_{t}-\varepsilon_{c t}\right) \\
& G_{f t}=G_{f c} / 250 \quad(\mathrm{MPa} \cdot \mathrm{mm})
\end{aligned}
$$

なお，圧縮側，引張側ともに原点指向の除荷経路 を用いた。

\section{(3) 鉄筋}

鉄筋の応力ーひずみ関係は，図-3に示すようにbilinearとし，降伏点以降の第二勾配は初期勾配の 1/100で増加し，除荷時には初期剛性で応力が減少 するモデルを使用した。また，コンクリートのひび 割れの有無にかかわらず，図-3から得られる鉄筋の 剛性と, 図-2から得られるコンクリートの剛性を重 ね合わせたRC要素を用いている。したがって，付 着は完全で鉄筋のすべりは生じないと仮定したこと になる。

\section{（4）等価長さ}

破壊エネルギーを考慮した構成則を用いる場合に は，ひずみとひび割れ幅を関連づけるための等価長 さ $\left(l_{e q}\right)$ が必要となる。等価長さの決定 ${ }^{7)}$ には, 「平面の対角線長さ」, 「立体の対角線長さ」, 「要素 3 辺の平均長さ」，「体積立方根」などを用 いて数種類の異なった要素分割モデルで解析を行っ た結果，簡便かつ要素分割依存性の影響が小さいも のとして要素の体積立方根（図-4）を採用した。

\section{（5）ひび割れモデル}

本解析手法では，ひび割れ発生後のコンクリート の構成則に分散ひび割れモデルの一種である，「不 連続回転ひび割れモデル8), 9), 10)」を使用した。この モデルは，「固定ひび割れモデル」と「回転ひび割 れモデル」の両者の長所を併せ持ったモデルである。 「不連続回転ひび割れモデル」は計算ステップごと に生じる主ひずみ方向の角度変化量 $\theta$ 小さい場合 には，「固定ひび割れモデル」としてひび割れ面を 固定しせん断伝達を許す。このときせん断剛性は山 田・青柳11) のモデルを使用した。 $\theta$ が大きいときに は，ひび割れを主ひずみ方向に回転させるので，せ ん断伝達は生じない。このため, 曲げ破壊のように ひび割れが構造物内に広く分散して破壊する場合や， せん断破壊のように少数のひび割れによって破壊が 誘起されるような場合でも解析に適用しやすい性質 を持っている。また本解析では，ひび割れの固定と 回転を制御する回転限界角 $\theta_{\lim }$ と，ひび割れ幅 $w$ の関 係 ${ }^{9)}$ は図-5のとおりとした。図-5のようにすること

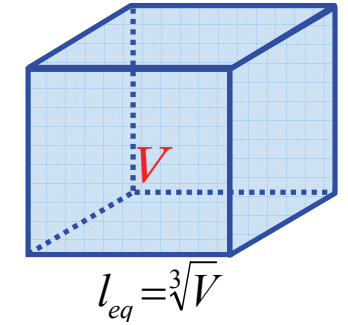

図-4 要素等価長さ

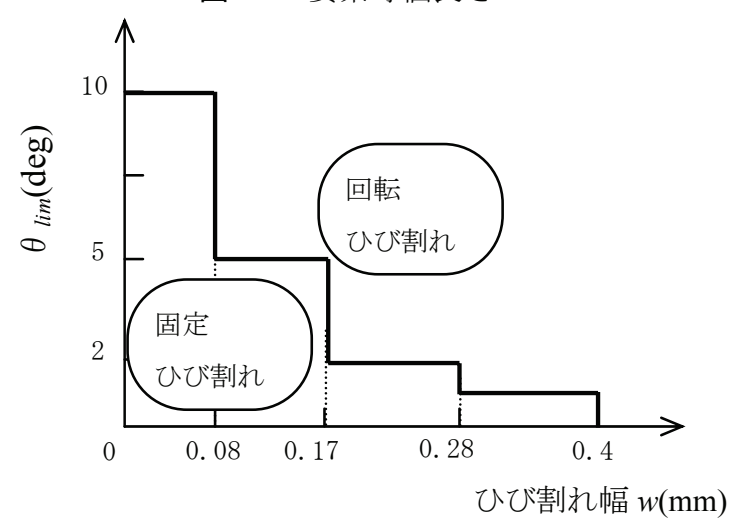

図－5 回転限界角一ひび割れ幅関係

により，ひび割れ幅が大きくなるに従ってひび割れ 面でのせん断伝達力が小さくなることを表現してい る.

\section{3. 薄いスラブの押抜きせん断挙動解析}

本章では，薄いスラブの押抜きせん断破壊性状に 着目して解析を行い, 本解析手法によって数值解析 的に破壊をどの程度再現できるか，またどのような 考慮が必要となってくるのかを検討する。

\section{(1) 実験の概要}

解析対象とした実験 ${ }^{3)}$ は RC スラブの押抜きせん 断破壊実験である。実験に用いた供試体の寸法

（図-6）は $1000 \mathrm{~mm} \times 1000 \mathrm{~mm} \times 100 \mathrm{~mm}$ でスパン長は $800 \mathrm{~mm}$ とした。配筋方法は単鉄筋直交配筋とし, 主鉄筋の有効高さ $\left(d_{m}\right)$ が $70 \mathrm{~mm}$, 配力鉄筋の有効高 さ $\left(d_{d}\right)$ が $60 \mathrm{~mm}$ であり 2 方向の平均有効高さ $(d)$ は $65 \mathrm{~mm}$ である。

使用した鉄筋の中心間隔は両方向ともに $50 \mathrm{~mm}$ で， 各断面における鉄筋比 $\left(p=A_{S} / b d\right)$ は, 主筋方向が $1.94 \%$, 配力筋方向が $2.26 \%$ であり，両方向の平均 は $p=2.10 \%$ である。鉄筋は, D10 で降伏応力は $377 \mathrm{MPa}$, ヤング係数は $1.86 \times 10^{5} \mathrm{MPa}$ のものを使用し た。また，支持部には幅 $75 \mathrm{~mm}$ の鋼支圧板を供試体 幅全長にわたって用い，相対 2 辺は浮き上がりを拘 束しないローラー支点により支持した。 なお，載荷 


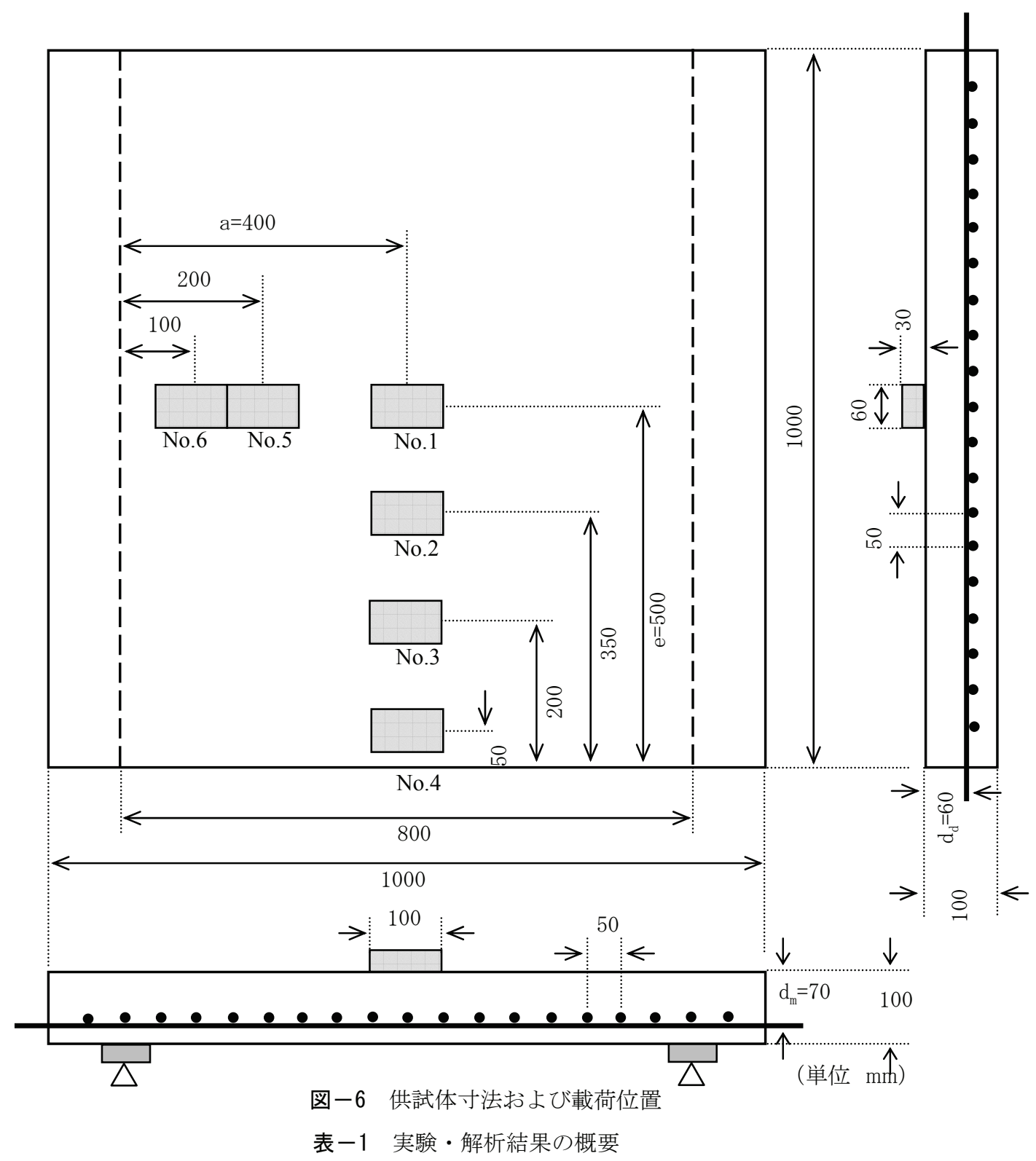

\begin{tabular}{|c|c|c|c|c|c|c|c|c|c|c|c|c|c|c|}
\hline \multirow[b]{2}{*}{$\begin{array}{c}\text { 供試体 } \\
\text { 番号 }\end{array}$} & \multirow[b]{2}{*}{$\begin{array}{l}\text { 圧縮強 } \\
\text { 度 (MPa) }\end{array}$} & \multirow[b]{2}{*}{$\begin{array}{c}\text { 鉄筋比 } \\
(\%)\end{array}$} & \multirow[b]{2}{*}{$\begin{array}{l}\text { 有効高 } \\
\text { さ (mm) }\end{array}$} & \multirow[b]{2}{*}{$\begin{array}{l}\text { 載荷周 } \\
\text { 長 (mm) }\end{array}$} & \multicolumn{2}{|c|}{ 載荷位置 (mm) } & \multirow[b]{2}{*}{$e / d$} & \multirow[b]{2}{*}{$a / d$} & \multicolumn{5}{|c|}{ 押抜きせん断耐力 (kN) } & \multirow[b]{2}{*}{$\mathrm{P}_{\mathrm{cal}} / \mathrm{P}_{\mathrm{e}}$} \\
\hline & & & & & $\begin{array}{l}\text { 自由緑まで } \\
\text { の距離 : e }\end{array}$ & $\begin{array}{l}\text { 支点まで } \\
\text { の距離 : a }\end{array}$ & & & 角田式 & $\begin{array}{l}\text { 前田· } \\
\text { 松井式 }\end{array}$ & 示方書 & $\begin{array}{c}\text { 実験値 } \\
: P_{\mathrm{e}}\end{array}$ & $\begin{array}{l}\text { 解析値 } \\
: P_{\text {cal }}\end{array}$ & \\
\hline No. 1 & 33.4 & 2.1 & 65 & 320 & 500 & 400 & 7.69 & 6.15 & - & - & 119 & 161 & 168 & 1.04 \\
\hline N0. 2 & 32. 3 & 2.1 & 65 & 320 & 350 & 400 & 5.39 & 6.15 & - & - & 119 & 150 & 164 & 1.09 \\
\hline No. 3 & 29.5 & 2. 1 & 65 & 320 & 200 & 400 & 3. 08 & 6.15 & - & - & 104 & 130 & 138 & 1.06 \\
\hline No. 4 & 30.2 & 2.1 & 65 & 320 & 50 & 400 & 0.77 & 6.15 & - & - & 71 & 73 & 90 & 1. 23 \\
\hline No. 5 & 28.0 & 2.1 & 65 & 320 & 500 & 200 & 7. 69 & 3.01 & - & - & 93 & 159 & 177 & 1.11 \\
\hline N0. 6 & 27.9 & 2.1 & 65 & 320 & 500 & 100 & 7.69 & 1.54 & - & - & 60 & 275 & 275 & 1.00 \\
\hline Case-1-1 & 19.6 & 2.1 & 65 & 320 & 500 & 400 & 7.69 & 6.15 & 114 & 162 & - & - & 120 & - \\
\hline Case-1-2 & 34.3 & 2.1 & 65 & 320 & 500 & 400 & 7.69 & 6.15 & 151 & 195 & - & - & 168 & - \\
\hline Case-1-3 & 49.0 & 2.1 & 65 & 320 & 500 & 400 & 7.69 & 6.15 & 180 & 216 & - & - & 201 & - \\
\hline Case-2-1 & 34.3 & 0.8 & 65 & 320 & 500 & 400 & 7.69 & 6.15 & 104 & 161 & - & - & 96 & - \\
\hline Case-2-2 & 34.3 & 1.4 & 65 & 320 & 500 & 400 & 7.69 & 6.15 & 139 & 179 & - & - & 141 & - \\
\hline Case $-3-1$ & 34.3 & 2.1 & 65 & 720 & 500 & 400 & 7.69 & 6.15 & 215 & 297 & - & - & 215 & - \\
\hline Case-3-2 & 34.3 & 2.1 & 65 & 1120 & 500 & 400 & 7.69 & 6.15 & 280 & 400 & - & - & 261 & - \\
\hline Case-4-1 & 34.3 & 2.1 & 95 & 320 & 500 & 400 & 7.69 & 6.15 & 258 & 281 & - & - & 265 & - \\
\hline Case-4-2 & 34.3 & 2.1 & 120 & 320 & 500 & 400 & 7.69 & 6.15 & 359 & 363 & - & - & 355 & - \\
\hline
\end{tabular}




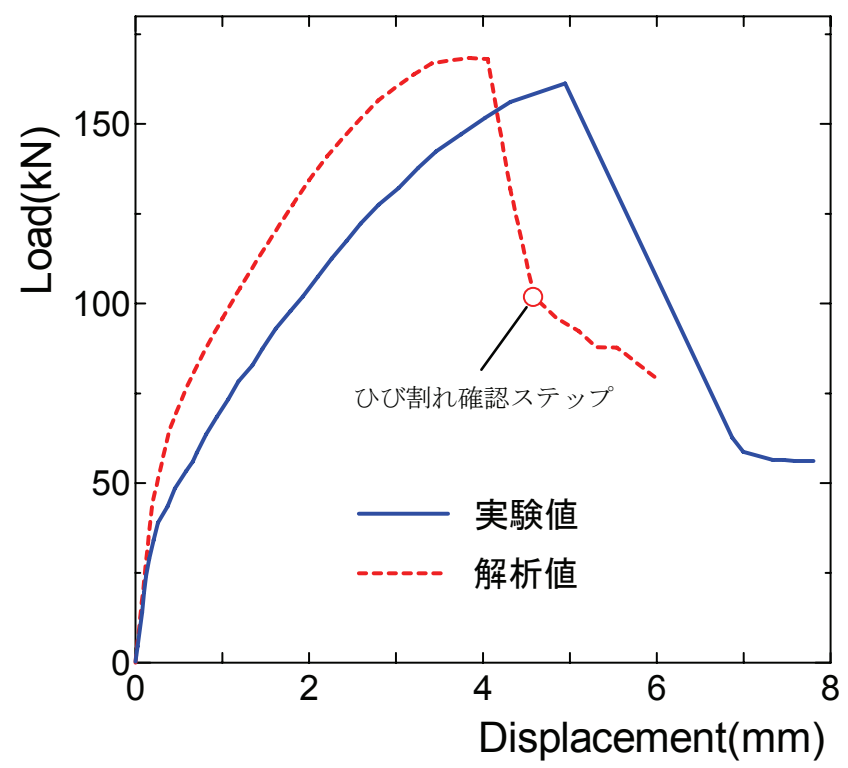

(a) No. 1 (e=500mm, a=400mm)

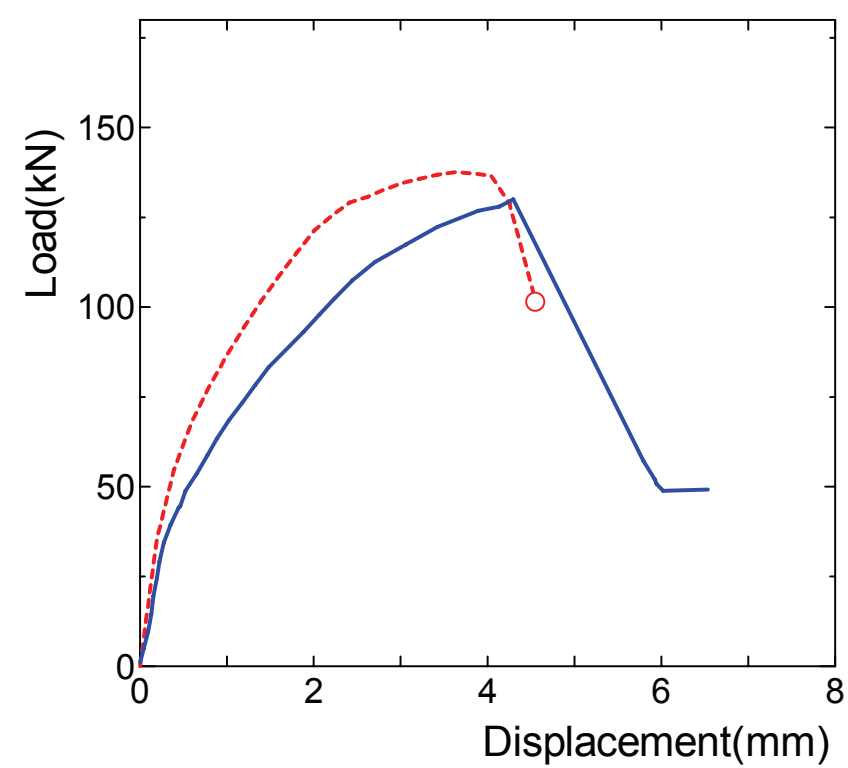

(c) No. 3 (e=200mm, a=400mm)

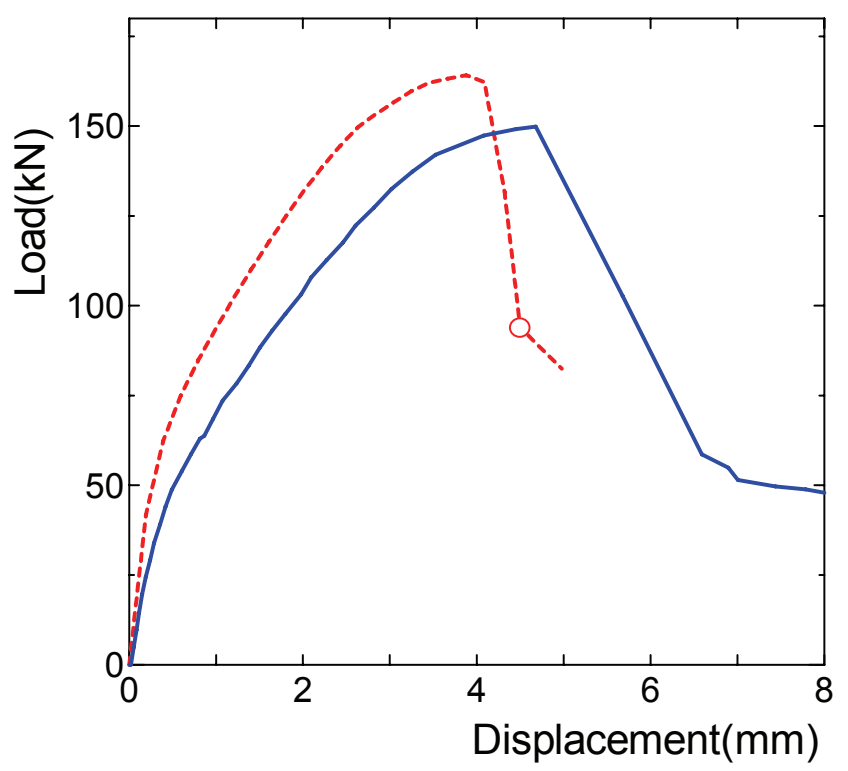

(b) No. 2 (e=350mm, a=400mm)

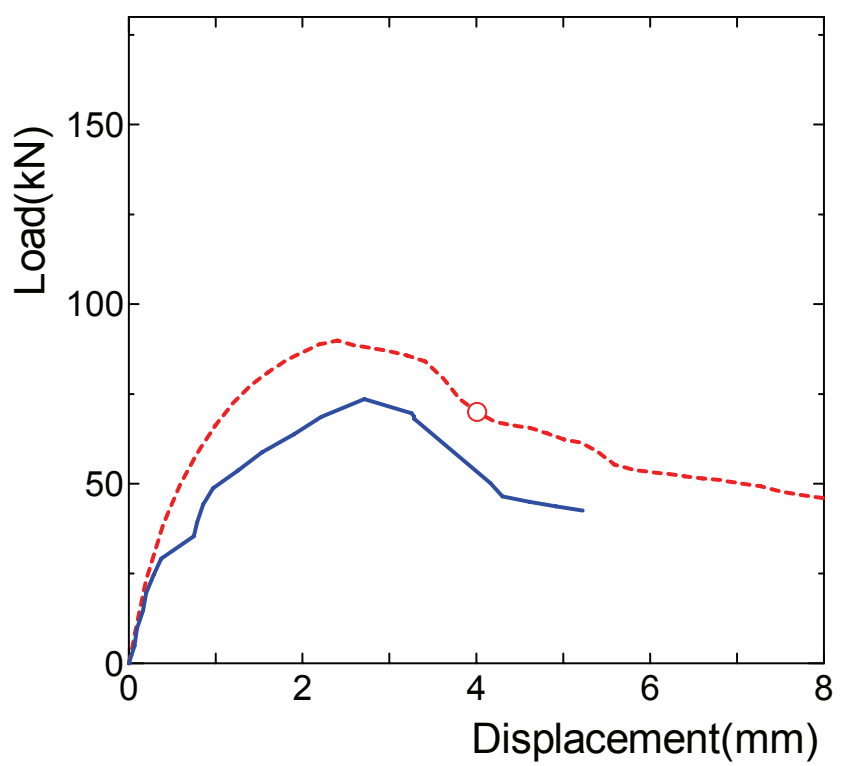

(d) No. 4 (e=50mm, a=400mm)

図ー7 (a)〜 (d) 載荷点を自由縁に近づけた場合の荷重一載荷点变位関係

点には $60 \times 100 \times 30 \mathrm{~mm}$ の鋼載荷板を用いた.

載荷方法は，載荷位置をスラブ中央から自由縁方 向に変化させた実験 No.1〜No.4 および，支点方向 に変化させた No.5, No.6の 2 種類とした.

実験において, 荷重は破壊に至るまで単調増加さ せ，荷重一載荷点変位関係を計測し，また破壊後に スラブを切断して斜めひび割れ状況を観察した。

なお，各実験における主要因子および，結果の概要 を表-1 に示す.

\section{a) 実験結果}

載荷位置を変化させたRCスラブの押抜きせん断 実験結果を表-1および，図-7，図-8に示す。図-7 (a 〜d) は載荷位置をスラブ中央から自由縁方向に近づ けたもの（No.1〜No.4）であり，図-8(a〜b) は載荷
点を支点方向に近づけたもの（No.5,6）である. 自 由縁までの距離を変化させたNo.1〜No.4の実験結果 では，最大荷重に達した後，急激に耐力を失う押抜 きせん断破壊の挙動を示している。また，その耐力 は, No.1 (中央載荷 $e=500 \mathrm{~mm})$ とNo.2 $(e=350 \mathrm{~mm})$ と では，10\%程度のわずかな違いしか見られないが, No.3 $(e=200 \mathrm{~mm})$ では, 中央載荷時の $81 \%$, No.4 $(e=500 \mathrm{~mm})$ では, 中央載荷時の $45 \%$ の值となり, 自由縁に近づくにつれて耐力は顕著に低下している. 載荷位置を支点方向に近づけた実験結果（No.5〜 No.6）について着目すると，No.5 $(a=200 \mathrm{~mm})$ では, 中央載荷時の $98 \%$ と変わらず, No.6 $(a=100 \mathrm{~mm})$ では 中央載荷時の $170 \%$ となり，載荷点が支点に接近す ると耐力が急増する性状が見られた。 


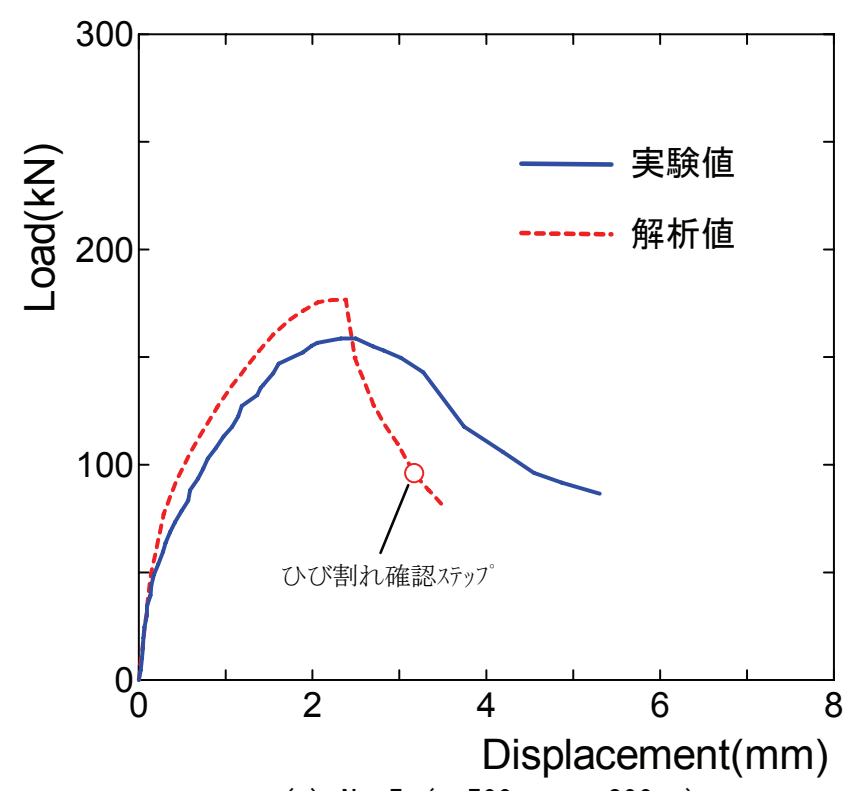

(a) No. 5 (e=500mm, a=200mm)

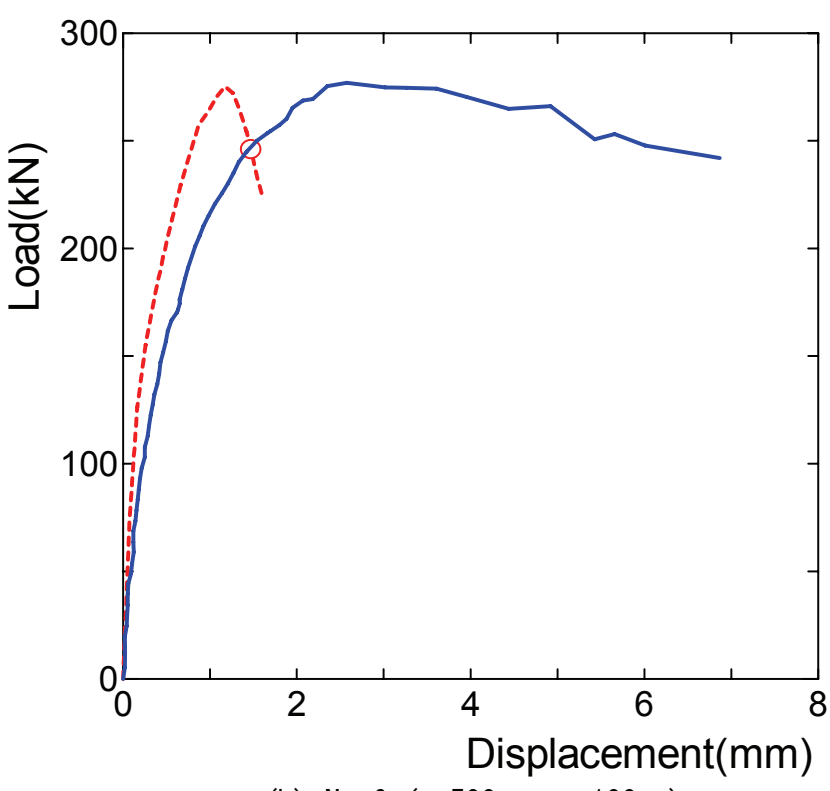

(b) No. 6 (e=500mm, a=100mm)

図ー8 (a) 〜 (b) 載荷点を支点に近づけた場合の荷重一載荷点変位関係

\section{b） 各種パラメーター解析における検討}

実験結果との比較検討を行う前に, 本解析手法の 信頼性を明らかにする必要がある。そのため, RC スラブの実験供試体の主要因子をパラメーターとし て変化させた解析結果と, これまでに提案されてい る経験的なRCスラブの押抜きせん断耐力評価式に よる計算值との比較を行い, 本解析手法における解 析値の妥当性を考察する. 解析において使用した要 素分割モデルの一例を図-9に示す，要素分割につい ての詳細は3.2に後述する.

変化させたパラメーターはコンクリート強度 $\left(f_{c}^{\prime}\right)$, 鉄筋比 $\left(p_{t}\right)$, 載荷板周長 $\left(b_{0}\right)$ および, スラブ有効高さ $(d)$ の 4 種類とした. 表-1 に併記 したとおり，コンクリート強度は 19.6，34.3，49.0

（MPa）と変化させ，鉄筋比は $0.8 ， 1.4 ， 2.1 （ \%)$, スラブ有効高さは $65,95,120(\mathrm{~mm})$, 載荷辺周 長は $320(100 \times 80) ， 720(200 \times 160) ， 1120$ （300×260）（mm）とした。また, 解析による耐 力との比較に使用した既往の押抜きせん断耐力評価 式は，角田式 ${ }^{2)}$ (式(9)），および前田・松井式 ${ }^{12)}$ (式(10)）である.

$P_{u}=0.211\left(b_{0}+3 \pi d\right) d \sqrt{f_{c}^{\prime}}\left(1+1.60 p f_{y} / \sqrt{f_{c}^{\prime}}\right) /(1+d / 200)$

$b_{0}:$ 載荷板周長 $(\mathrm{mm})$

$f_{y}:$ 引張鉄筋の降伏点 $(\mathrm{MPa})$

$f_{c}^{\prime}:$ コンクリート圧縮強度 $(\mathrm{MPa})$

$d:$ 二方向の平均有効高さ $(\mathrm{mm})$

$p:$ 二方向の平均鉄筋比 $(\%)$

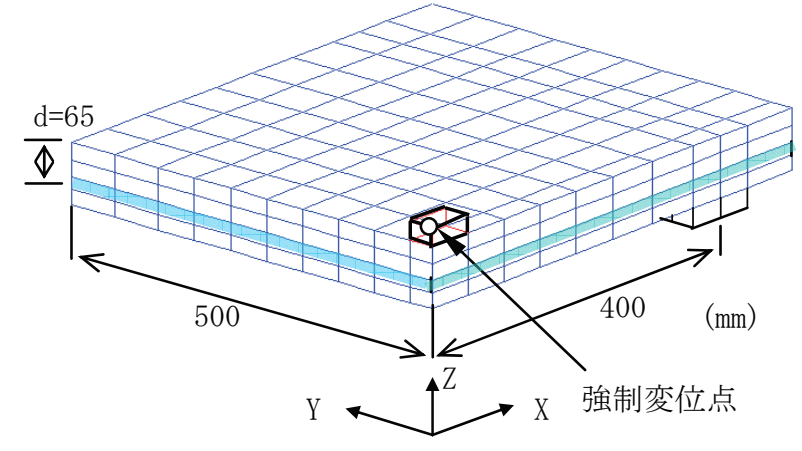

図－9 要素分割モデルの一例（対称 $1 / 4$ モデル）

ただし,$p f_{y} / \sqrt{f^{\prime}{ }_{c}} \leq 10.4$

$$
\begin{aligned}
P_{u} & =\tau_{s \max }\left\{2\left(a+2 x_{m}\right) x_{d}+2\left(b+2 x_{d}\right) x_{m}\right\} \\
& +\sigma_{t \max }\left\{2\left(4 C_{d}+2 d_{d}+b\right) C_{m}+2\left(a+2 d_{m}\right) C_{d}\right\}
\end{aligned}
$$

$a, b \quad$ : 載荷板の辺長, $x_{m}, x_{d}$ : 中立軸深さ

$C_{m}, C_{d}$ : 鉄筋の芯かぶり $d_{m}, d_{d}$ : 有効高さ

$$
\begin{aligned}
& \tau_{s \max }=0.252 f_{c}-0.00251 f_{c}^{2} \quad(\mathrm{MPa}) \\
& \sigma_{t \max }=0.269 f_{c}^{2 / 3} \quad(\mathrm{MPa}) \\
& E_{c}=20594+900\left(f_{c}^{\prime}-29.42\right) \quad(\mathrm{MPa})
\end{aligned}
$$

各パラメーターをそれぞれ変化させた場合の，耐 力評価式での計算值と, 本解析手法による解析值を 表-1 (Case-1-1〜Case-4-2) に示寸. 図-10 (a) はコンク リート強度と耐力の関係を, 図-10(b) は鉄筋比と耐 力の関係, 図-10 (c) は載荷周長と耐力の関係, 図10 (d) は有効高さと耐力の関係を示す. 


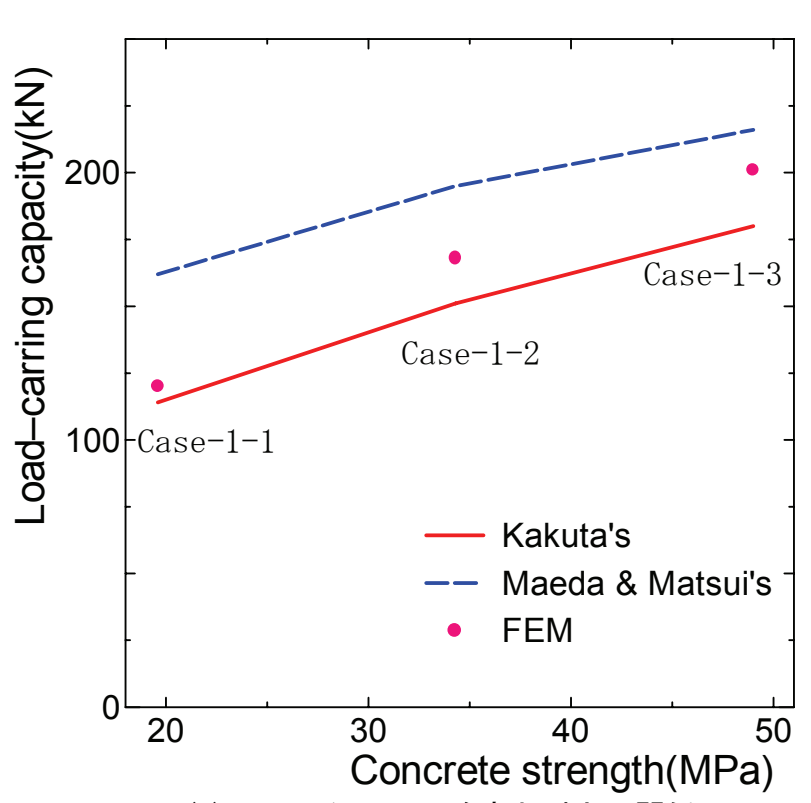

（a）コンクリート強度と耐力の関係

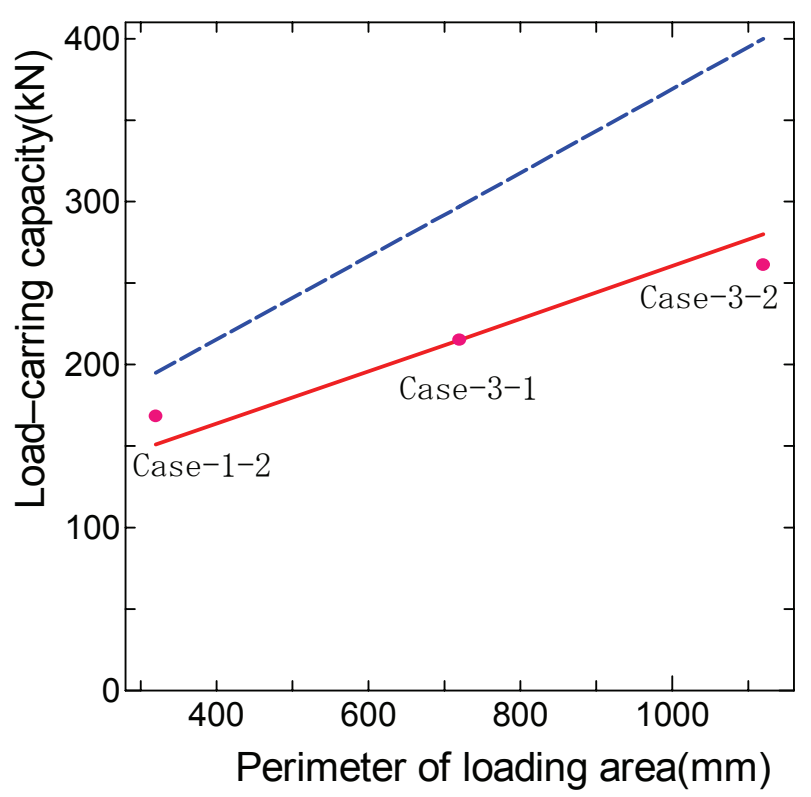

(c) 載荷周長と耐力の関係

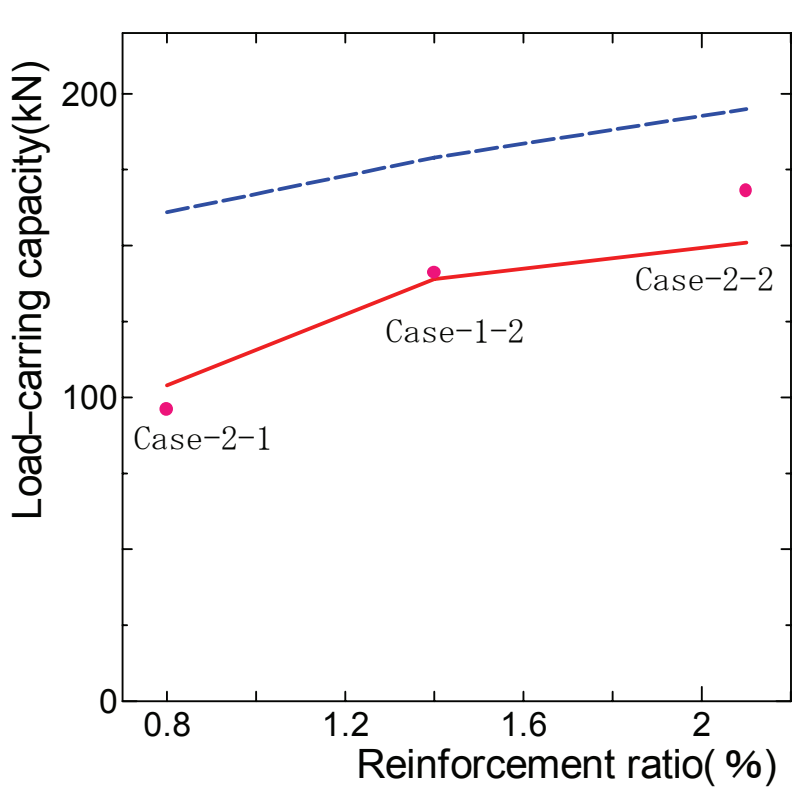

(b) 鉄筋比と耐力の関係

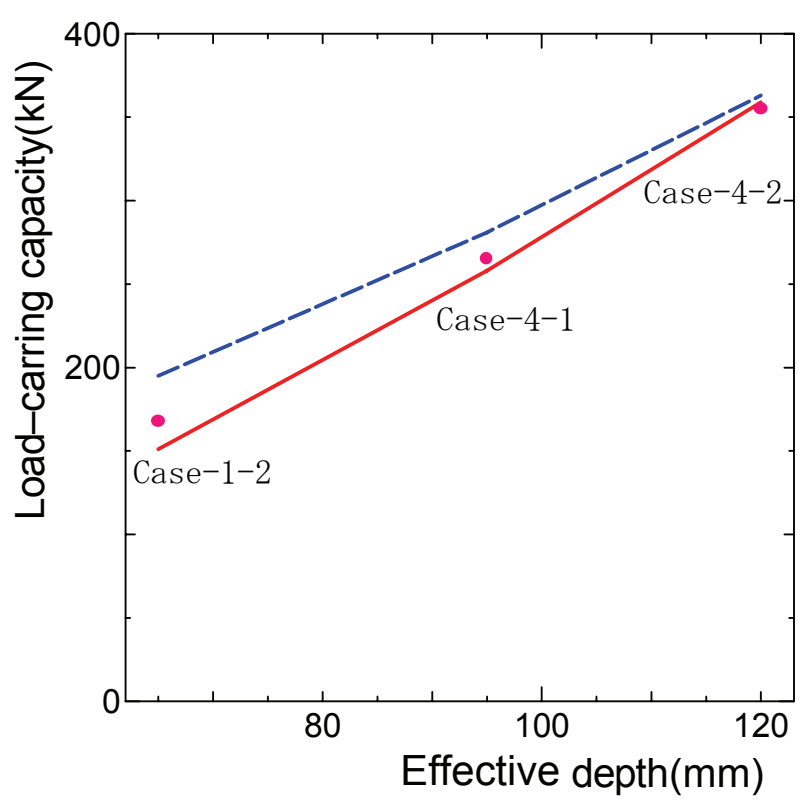

(d) 有効高さと耐力の関係

図ー10 (a) 〜 (d) 各種パラメーターと耐力の関係

各解析耐力に着目すると，図-10 (a) から，コンク リート強度が小さいときには, 角田式に近い数值を 示しており，コンクリート強度が大きくなるにつれ て, 徐々に前田・松井式に近づく傾向にあるが，コ ンクリート強度に関わらず, 両経験式の中間的な数 值を示していることがわかる．図-10(b)から，鉄筋 比が比較的小さいときには角田式とほぼ同等である が，鉄筋比が大きいときは前田・松井式に若干近づ くこと, 図-10 (c) から, 載荷周長の影響は前田・松 井式よりかなり小さく角田式に近い結果であるが, 角田式よりもさらに幾分小さい傾向があること, 図-10 (d) 加 , 有効高さの影響は両式とも大差ない のであるが，解析值は両者の中間であることが分か
る。したがって，本解析手法を用いることによって， 押抜きせん断耐力に大きな影響を与える因子である コンクリート強度, 鉄筋比, 載荷周長および, 有効 高さの影響を妥当な範囲で評価できることが確認で きた。

\section{（2）載荷位置を変化させたスラブの押抜きせん断 破壊}

次に，載荷点をスラブ中央から自由縁方向に近づ けた場合および，支点方向に近づけた場合の実験結 果とFEMによる解析結果の比較検討を行う.

a) 解析モデル

本解析で用いた要素分割の例を図-9 に示寸．鉄 


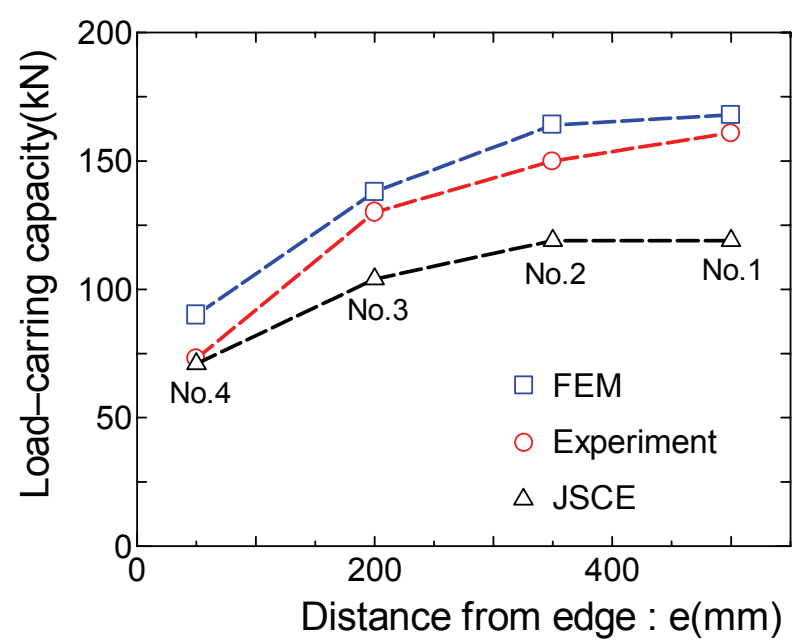

(a) 自由縁までの距離と耐力の関係

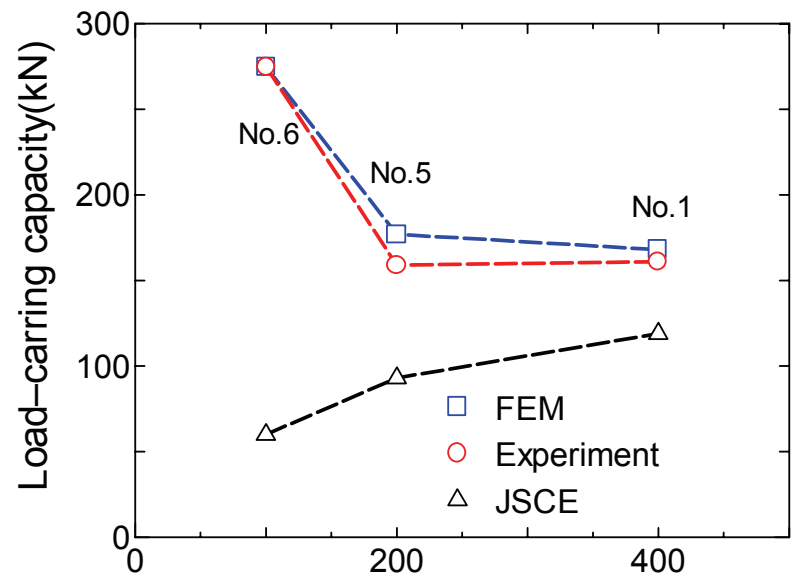

Distance from supporting point $: a(\mathrm{~mm})$ (b) 支点までの距離と耐力の関係

図－11 載荷位置による耐力の変化

筋は要素中に平均的に存在すると仮定した $\mathrm{RC}$ 要素 を用いるので，主鉄筋有効高さと配力鉄筋有効高さ の中央点が鉄筋を含む $\mathrm{RC}$ 要素（下から 2 層目）の 図心位置と一致するように分割した，要素分割モデ ル No.1（中央載荷時）は，2 方向の対称性を考慮し た 1/4 モデルを用いた. No.2〜No.4 はスパン方向の 対称性の夕を考慮した 1/2 モデルを，No.5〜No.6 は 奥行き方向の対称性のみを考慮した $1 / 2$ モデルを用 いた。 また, 使用した $1 / 2$ モデルは, $1 / 4$ モデルを単 純に並べたものである，支点での境界条件としては $Z$ 方向変位のみを拘束している.

\section{b）荷重一載荷点変位関係}

載荷点を自由縁に近づけて行った場合であるNo.1

〜No.4の実験と解析結果に着目寸る.

まず，表-1 に示す押抜きせん断耐力を比較する と, No.1〜No.4 の解析值はそれぞれ実験值の 104\%, 109\%，106\%，123\%であり，解析耐力は実験耐力を 若干大きく評価寸る傾向にはあるが，概ね評価出来 ている。また，破壊に至るまでの挙動に着目すると， 曲げひび割れ発生後の剛性の低下が実験值に比べて 小さく, 最大荷重時の変位は実験変位の $80 \%$ ～95\% と幾分小さいものの, 解析結果としては満足できる ものと考えられる.

次に，載荷点を支点方向に近づけた No.5, No.6 に着目する. No.5 の解析結果は，押抜きせん断耐力 を実験の $111 \%$ と概敉算定できている。また，荷重 一変位関係も他の解析結果と比べて実験結果を良く 表している. No.6 の解析耐力は，実験の $100 \%$ とな り, 非常に精度は高かった。しかし, 最大荷重後の 緩やかに荷重が低下寸る挙動は再現できなかった。

この理由は明らかではないが, この実験では, 載 荷板と支圧板の縁端距離が極めて小さいため，一面 せん断状態のような特殊な状態になっていることな どによるものと推測される.

\section{c）載荷位置による耐力の変化}

RCスラブの押抜きせん断実験により, 載荷位置 によって押抜きせん断耐力が変化することが明らか となった，載荷位置が自由縁に近づくと耐力は低下 し，支点に近づくと耐力は増加する。このような性 状が解析において表現できるか検討を行った。

図-11 (a) は載荷点を自由縁に近づけたときの耐力 の変化を表す。自由縁から最も遠い No.1 $(e=500 \mathrm{~mm})$ が実験・解析ともに最も耐力が大き く, 自由縁に近づくにつれて耐力が低下し, No.4 ( $e=50 \mathrm{~mm})$ の解析では, 最も耐力が小さい結果 となり, FEM 解析は実性状を非常に良く表してい る. また, 土木学会コンクリート標準示方書 ${ }^{13)}$ には スラブの押抜きせん断耐力の算定方法として，面部 材式も示されいるが, 面部材式では, 載荷位置の違 いを考慮出来ないために，ある有効幅 $\left(b_{e}\right)$ をもつ， はり部材としてせん断耐力を算定する方法（式 11）による結果を表-1 ならびに図-11 に $\triangle$ 印で示し た.

$$
\begin{gathered}
V_{c d}=\beta_{p} \cdot \beta_{d} \cdot \beta_{n} \cdot f_{v c d} \cdot b_{e} \cdot d \\
c \geq 1.2 x(1-x / l) \text { の場合 } \\
b_{e}=v+2.4 x(1-x / l) \\
c<1.2 x(1-x / l) \text { の場合 } \\
b_{e}=c+v+1.2 x(1-x / l) \\
f_{v c d}=0.20 f_{c}^{11 / 3} \quad\left(\mathrm{~N} / \mathrm{mm}^{2}\right) \\
\beta_{p}=\left(\begin{array}{ll}
100 & p
\end{array}\right)^{1 / 3} \\
\beta_{d}=\sqrt[4]{1 / d} \quad(d: \mathrm{m})
\end{gathered}
$$




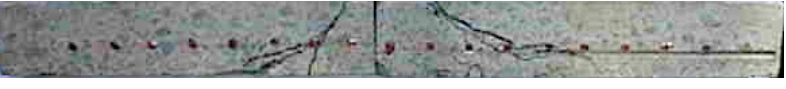

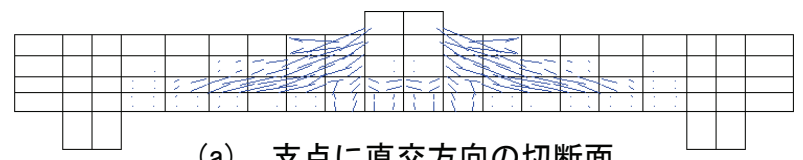

（a）支点に直交方向の切断面

図-12 No.1のひび割れ性状
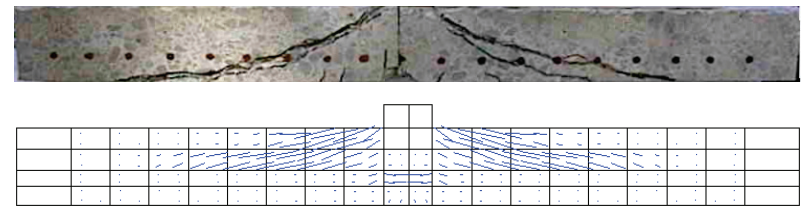

(b) 支点に平行方向の切断面
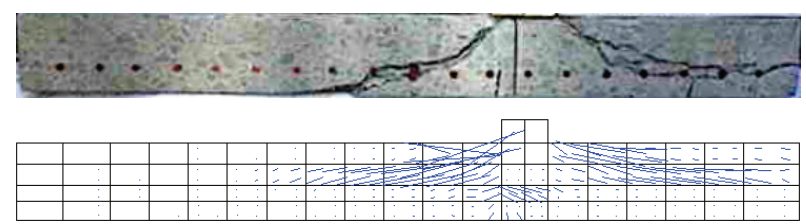

(b) 支点に平行方向の切断面

図ー13 No.2のひび割れ性状
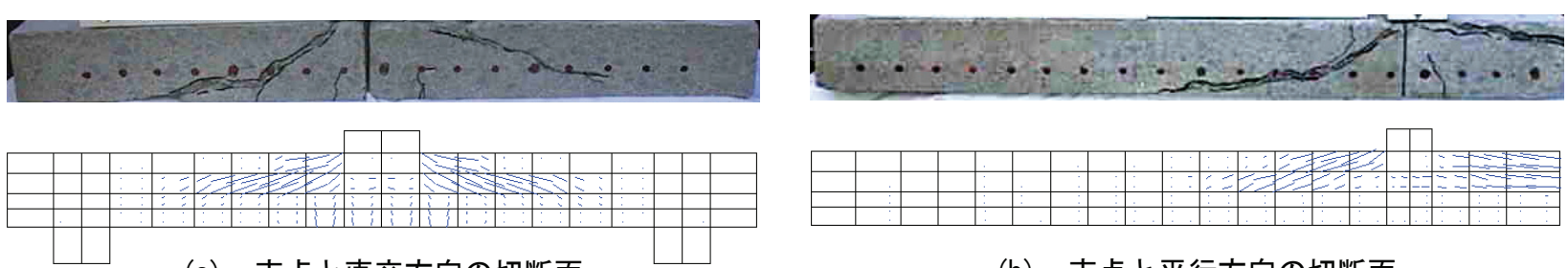

（a）支点と直交方向の切断面

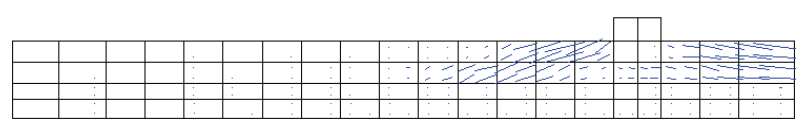

(b) 支点と平行方向の切断面

図ー14 No.3のひび割れ性状
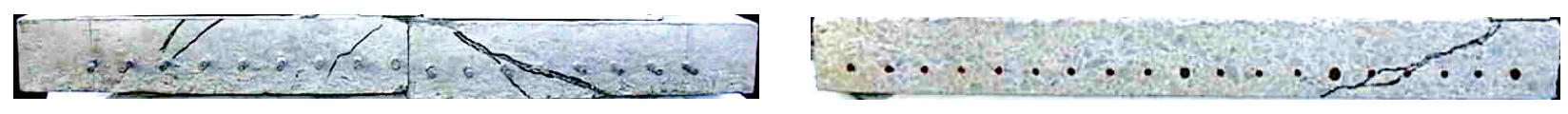

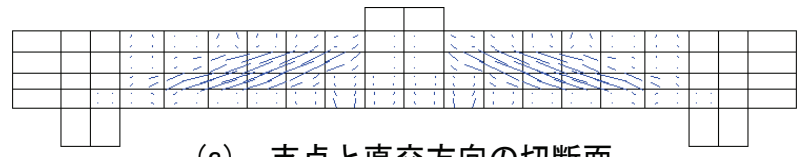

（a）支点と直交方向の切断面

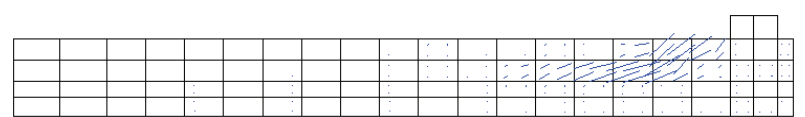

(b) 支点と平行方向の切断面

図ー15 No.4のひび割れ性状

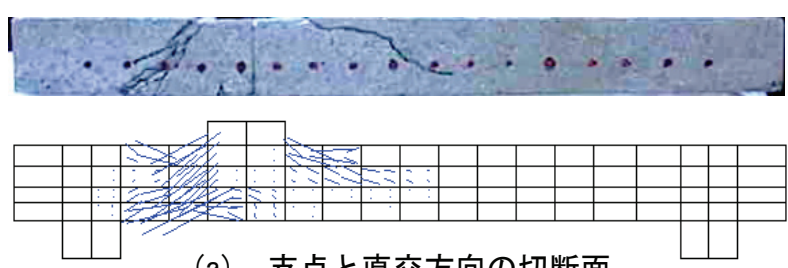

（a）支点と直交方向の切断面

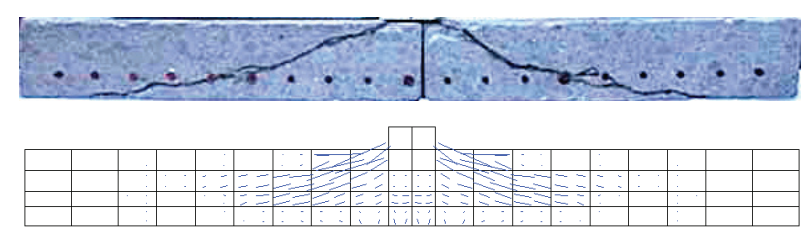

（b）支点と平行方向の切断面

図－16 No.5のひび割れ性状

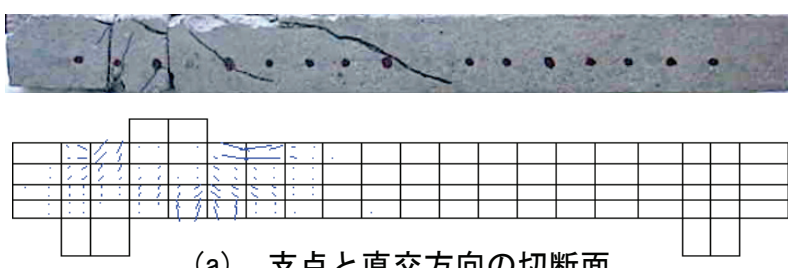

（a）支点と直交方向の切断面

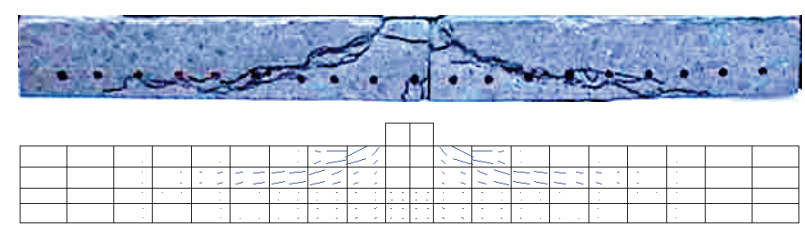

（b）支点と平行方向の切断面

図ー17 No.6のひび割れ性状

$\beta_{n}=1 \quad(N=0$ の場合 $)$

$c$ : 集中荷重の分布幅の端からスラブ自由 縁までの距離

$x$ : 集中荷重作用点から最も近い支点まで の距離

$l:$ スラブのスパン
ただし, 各実験供試体におけるコンクリート強度 には大きな違いがないため, 中央載荷供試体のコン クリート強度を用いて算定值とした。図-11(a)より， 示方書の方法では, 全体的に耐力を小さく評価して いること, また荷重が自由縁に近づいた場合の耐力 低下を過小評価していることが分かる。図-11(b) は， 載荷点を支点に近づけたときの押抜きせん断耐力の 

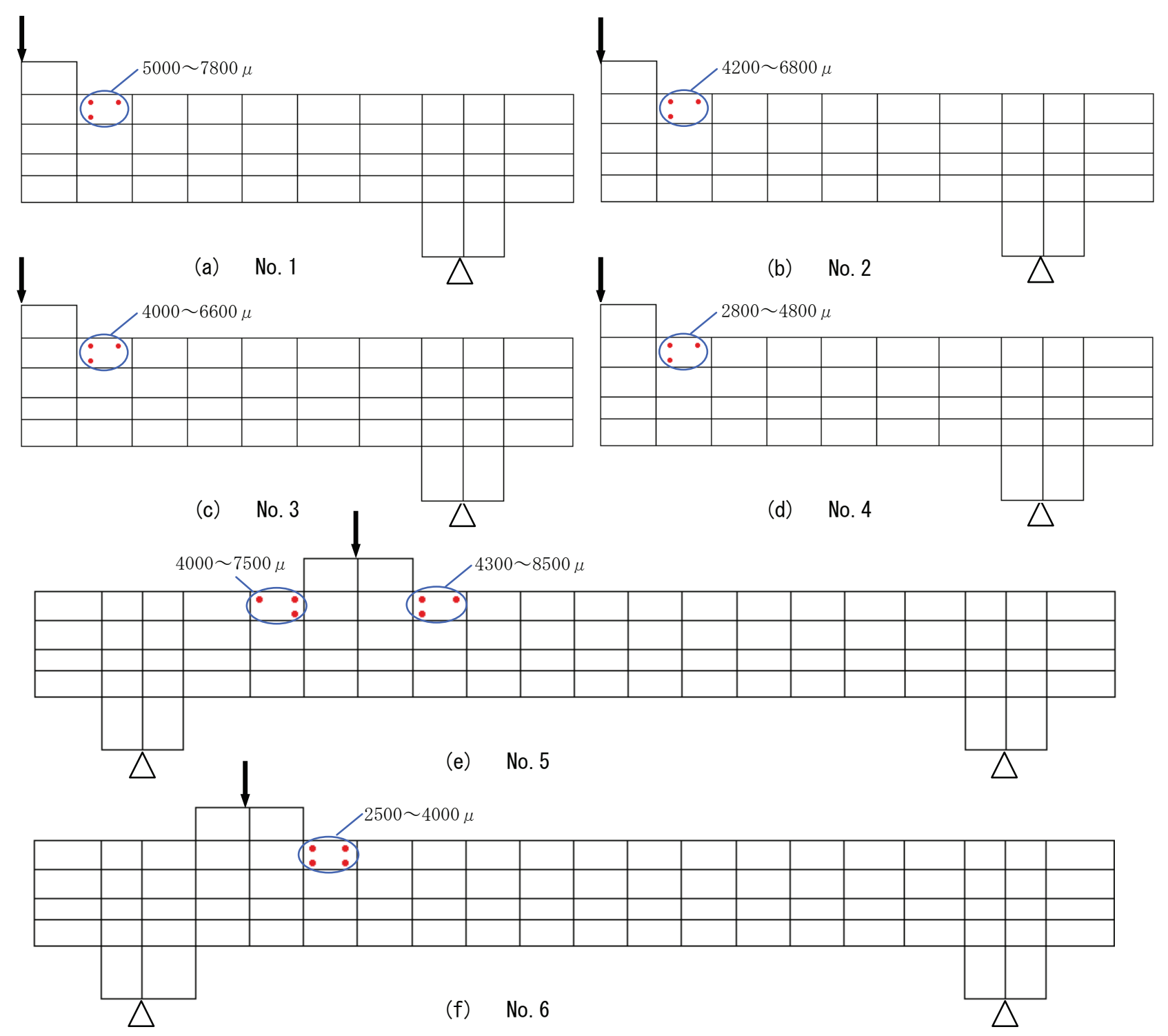

図ー18 圧縮軟化した Gauss point 分布

変化を表す。図-11 (b)より, 示方書式では, 載荷点 が支点に近づくにつれて耐力が低下する結果となる が，解析では，載荷点と支点の距離が $200 \mathrm{~mm}$ 以下 で, 寸なわち a/d が 3.0 程度以下で, 耐力が急激に 増加する傾向を良く再現している。 したがって，解 析によって載荷点が自由縁に近づいた場合の耐力低 下および，支点に近づいた場合の耐力増加を評価で きることがわかる.

\section{d）ひび割れ性状}

本解析によって, 荷重一変位関係, 押抜きせん断 耐力を再現出来ることがわかった，次に，押抜きせ 几断破壊時における斜めひび割れ性状を解析によっ て表現出来るか否かを検討する，ひび割れの比較検 討には, 載荷板の中央を通り支点に直交方向の切断 面と, 支点に平行方向の切断面を用いた. 解析での ひび割れ図は，最大引張ひずみ $\left(\varepsilon_{1}\right)$ の直交方向に 引いた線でひび割れ方向を示し，ひずみの大きさを
線の長さとして示したものである. 図-7，8中の○ 印は荷重ピーク後に斜めひび割れが卓越したステッ プを示しており, 図12〜17でひび割れを描写した時 点を示す.

まず，載荷点が自由縁から十分に離れている No.1 〜No.2 に着目寸る. 支点直交方向のひび割れ性状

（図-12 (a), 図-13 (a)) は, 斜めひび割れの発生位 置・角度ともにおおむ敉実験結果と一致している。 支点平行方向のひび割れ性状（図-12(b), 図$13(b))$ では, 斜めひび割れが実験結果よりもフラ ットに発生している.

次に, No.3〜No.4の, 載荷点が自由縁に近い場合 に着目する，支点直交方向のひび割れ性状（図一 14 (a), 図-15(a)) は, おおむ敉実験結果と一致し ている. 支点平行方向のひび割れ性状（図-14(b), 図-15(b)）では，載荷点より中央側の斜めひび割れ がフラットになっている点が実験とはやや異なって 
表－2 フーチングの実験・解析概要

\begin{tabular}{|c|c|c|c|c|c|c|c|c|c|c|}
\hline \multirow{2}{*}{$\begin{array}{l}\text { 供試体 } \\
\text { 番号 }\end{array}$} & \multirow{2}{*}{$\begin{array}{c}\text { 圧縮強度 } \\
(\mathrm{MPa})\end{array}$} & \multirow{2}{*}{$\begin{array}{c}\text { 有効高さ } \\
\mathrm{d}_{1}(\mathrm{~mm})\end{array}$} & \multirow{2}{*}{ 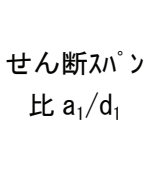 } & \multirow{2}{*}{$\begin{array}{c}\text { 鉄筋比 } \\
\quad(\%)\end{array}$} & \multicolumn{2}{|c|}{ 斜めひび割れ荷重 (kN) } & \multirow[b]{2}{*}{$P_{c r, c a l} / P_{c r, e x}$} & \multicolumn{2}{|c|}{ 最大荷重 (kN) } & \multirow[b]{2}{*}{$P_{\max , \text { cal }} / P_{\max , e}$} \\
\hline & & & & & $\begin{array}{c}\text { 実験値 } \\
P_{c r, e x}\end{array}$ & $\begin{array}{l}\text { 解析値 } \\
P_{c r, c a l}\end{array}$ & & $\begin{array}{r}\text { 実験値 } \\
P_{\max , e x}\end{array}$ & $\begin{array}{l}\text { 解析値 } \\
P_{\text {max }, \text { cal }}\end{array}$ & \\
\hline 5405 & 19.9 & 330 & 1.52 & 0.768 & 373 & 460 & 1.23 & 588 & 613 & 1.04 \\
\hline 5406 & 20.3 & 250 & 2.00 & 0.760 & 324 & 337 & 1.04 & 343 & 359 & 1.05 \\
\hline 5408 & 19.7 & 250 & 2.00 & 1.01 & 304 & 325 & 1.07 & 343 & 368 & 1.08 \\
\hline 5411 & 20.6 & 500 & 1.00 & 0.456 & 785 & 750 & 0.96 & 873 & 964 & 1.10 \\
\hline
\end{tabular}

いる.

載荷点を支点に近づけた No.5〜No.6 に着目する. No.5 は，支点直交方向（図-16(a)）および平行方向 （図-16(b)）ともに，斜めひび割れの再現性は高い. No.6 は，支点直交方向の斜めひび割れ（図-17(a)) があまり発達しない点が実験結果と一致しており， 支点平行方向の斜めひび割れ（図-17(b)) は，実験 結果に比べるとややフラットに発生している.

このような斜めひび割れの傾向となる理由として は，支点と直交方向では載荷点から支点に向けて直 接的に力が伝達されるため, 載荷点と支点を結ぶ方 向に斜めひび割れが発生するが，支点と平行方向で は，力を伝達すべき支点が存在しないので，鉄筋を 配置してある層の上縁に沿うように斜めひび割れが 発生することになるためと推測される.

\section{e） スラブの破壊モードに関する考察}

前項で，各押抜きせん断破壊供試体について，斜 めひび割れ性状を確認し，解析でも実験の斜めひび 割れ性状を非常に良く捉えることが出来た。さらに， 解析結果に基づいて破壊モードの考察を行った。 図-18 は，各解析でのピーク荷重時における圧縮軟 化した Gauss 点の分布を示したものである.

No.1〜No.6 では，圧縮軟化した Gauss point は, 載荷板に隣接した要素にしか存在せず，軟化の分布 範囲は狭い。また，ひずみの值も圧縮軟化後の急激 な増大は示していない。したがって，押抜きせん断 破壊に対する圧縮軟化の影響は小さく, 主として斜 めひび割れが発達することによって破壊が誘起され たものと考えることができる.

\section{4. 厚いスラブのせん断挙動解析}

\section{（1） フーチングの押抜きせん断破壊性状}

3章では二辺を単純支持した薄いスラブについて 検討した。ここでは，フーチングのような厚みのあ るRCスラブを柱で支持する様な場合で，せん断ス パンが比較的小さい場合の押抜きせん断破壊を対象 として検討を行う。
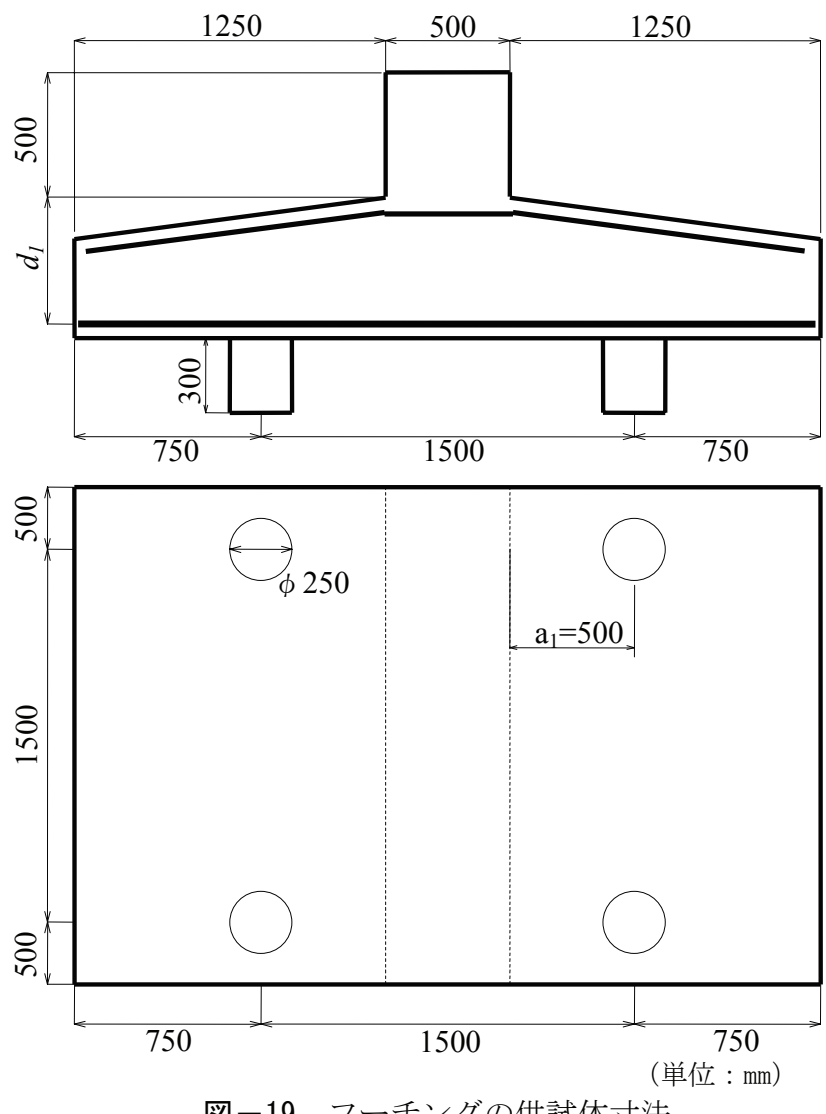

図－19 フーチングの供試体寸法

a） 実験の概要

本検討で用いた実験結果は，石橋ら ${ }^{14)}$ が実施した 壁式橋脚を有するフーチングの押抜きせん断破壊試 験の結果である。供試体は図-19 に示すように，ス パン長が $1500 \mathrm{~mm}$, 張り出し長が両側に $750 \mathrm{~mm}$, フ 一チング幅が $2000 \mathrm{~mm}$ のものである. フーチングの 上部中央に壁が設けてあり，下部には直径 $250 \mathrm{~mm}$ のコンクリート円柱杭が 4 本設けてある。供試体 5406，5408 は同一寸法のフーチングで鉄筋量を変化 させてある. 5405 および 5408 は，鉄筋量などは同 一で有効高さのみ変化させた実験である，実験では 供試体の杭より載荷が行われ, 破壊時の杭一本あた りの最大荷重が計測されている。各供試体の諸元を 表-2 に示す. 表-2 のせん断スパン比 $\left(a_{1} / d_{1}\right)$ に用 いる $a_{1}$ は，壁の端部から杭の中央までの距離とした。 また，鉄筋比としては，二方向に配置された下段鉄 


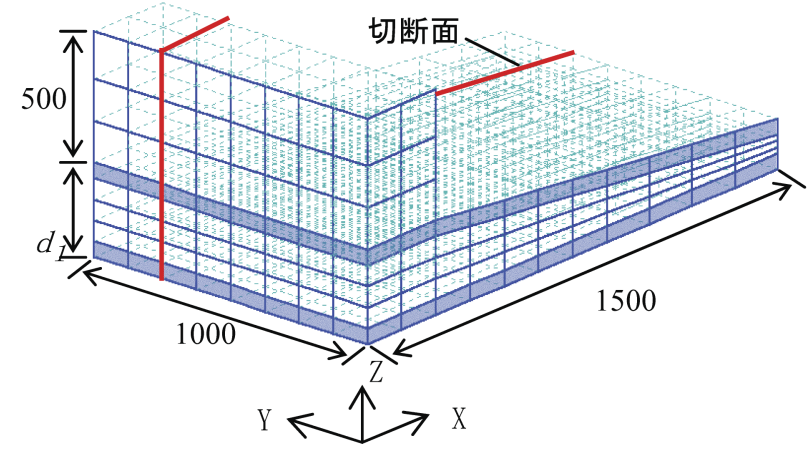

図-20 要素分割図（対称 $1 / 4$ モデル）の一例

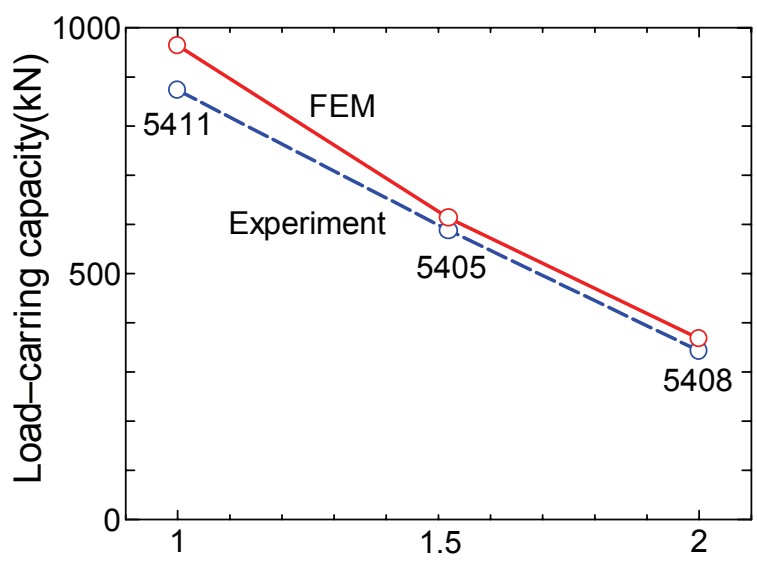

Shear span-depth ratio

図一22 せん断スパン比による耐力変化

筋の平均鉄筋比 $\left(p_{t}=A_{S} / b d_{1}\right)$ を用いた。なお，耐荷 力は杭一本あたりの荷重で示している.

\section{b) 解析モデル}

本検討で使用した要素分割図を図-20 に示す。要 素分割は， $X=0$ の面での $X$ 方向の対称性， $Y=0$ の面 での $Y$ 方向の対称性を考慮した $1 / 4$ モデルである. なお，鉄筋は RC 要素としてモデル化した。実験で は杭は円柱であるので, 解析でも円柱としてモデル 化するのが適当ではあるが，計算上の簡便性のため， 壁と杭の純間隔が実験と等しくなるような， $250 \mathrm{~mm}$ $\times 250 \mathrm{~mm}$ の正方形断面の柱としてモデル化した.

\section{c） 実験耐力と解析耐力の比較}

RCフーチングの実験結果と解析結果を表-2に示 す。解析では， 4 供試体ともに，斜めひび割れ発生 後も荷重が増加し, 最大荷重に到達後, 緩やかに荷 重が低下した。これは， shear band 部にアーチ型の 耐荷機構が発生したためだと考えられる。続いて解 析による荷重一変位関係を図-21に示す. 図-21中の $\triangle$ 印は斜めひび割れが発生した時点を示す。解析精 度に着目すると, 斜めひび割れ発生荷重は実験值の 96〜 123\%で，最大荷重は実験值の104～110\%であり，
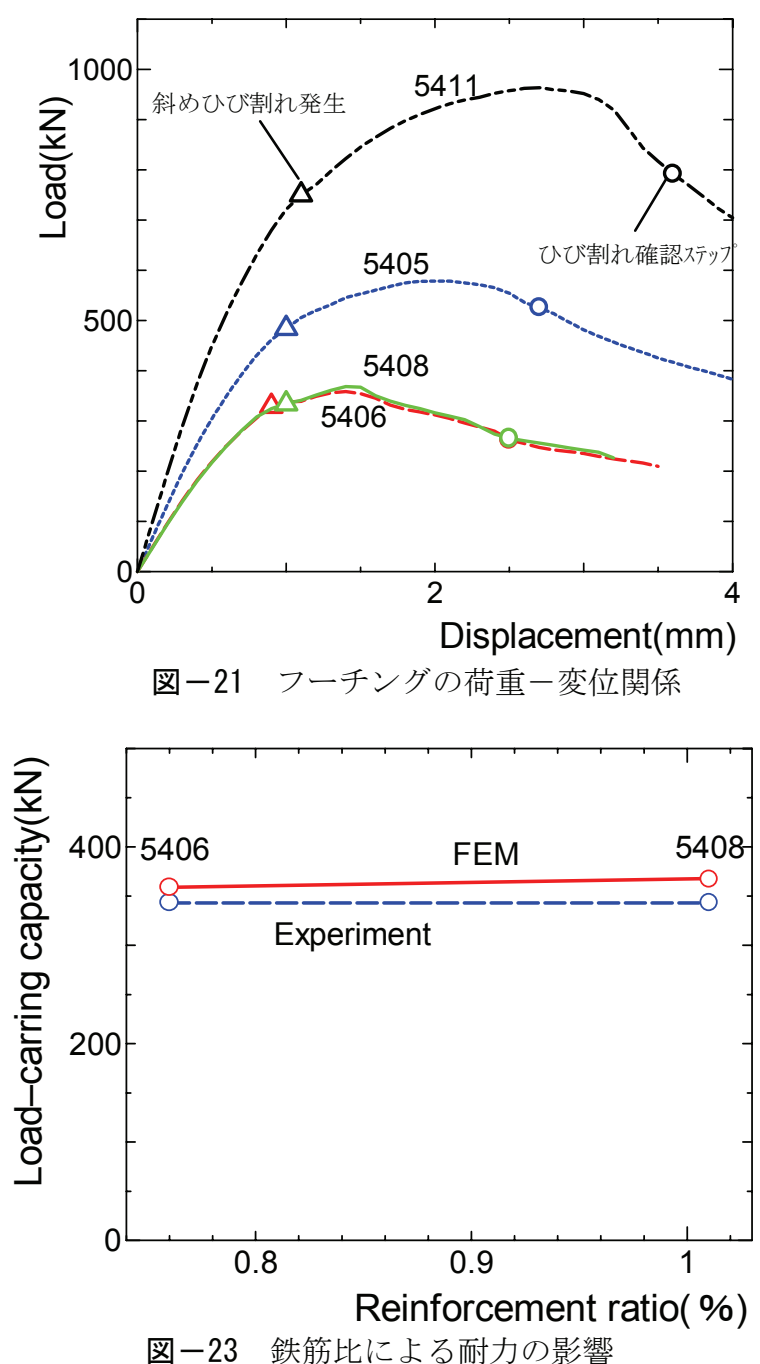

いずれも概ね評価できている.

次に，せん断スパン比が押抜きせん断耐力に及ぼ す影響を図-22に示す。図-22中の実線が解析值, 破 線が実験值を示す。着目したのは供試体5405，5408 および5411である。実験では，せん断スパン比が大 きくなると, せん断耐力が小さくなるが，解析にお いても同様の結果が再現されている.

続いて鉄筋比が押抜きせん断耐力に及ぼす影響に ついて示す（図-23）。実験では, 鉄筋比が増加し ても大きな耐力増加は見られない。 また，解析にお いても鉄筋比の違いによる耐力の変化は大きく現れ ておらず, 実験での傾向と一致している.

\section{d）ひび割れ性状の比較}

押抜きせん断破壊の解析において，耐力を評価す ることは重要事項であるが, 破壊性状の評価も極め て重要である。そのため， RCフーチングの押抜き せん断破壊時における実験および，解析での斜めひ び割れ性状を比較検討する。図-24は，実験でフー チング側面まで到達したひび割れと，解析によるひ び割れを示す。実験では，せん断スパン比および鉄 筋比の違いによらず，載荷面から支圧板に向かって 
斜めひび割れが卓越していることが分かる．解析で も，実験性状を良く捉えており，斜めひび割れの位 置，角度ともに良く一致している．また，実験では， 断面上部から支点に向けて曲げひび割れが発生して いる. 解析でも，断面上部から発生したひび割れは 認められるが，発生位置が若干スパン中央側に現れ る傾向にある。この曲げひび割れがいつの時点で発 生したものか文献では明記されていないため断定で きないが，破壊後に 2 次的に発生した可能性もある。 したがって，このようなひび割れの再現は困難であ ったが，解析によって押抜きせん断破壊性状を概秝 再現できるものと言える.

\section{e） フーチングの破壊モードに関する考察}

$\mathrm{RC}$ フーチングの様な厚みのある部材の押抜きせ 几断破壊では，コンクリートの圧縮軟化がせん断耐 力に及ぼす影響が大きいことも考えられる，そのた め, 最大荷重時に圧縮軟化した要素Gauss pointの分 布に着目する。図-25は，RCフーチング試験供試体 の中で, 最も厚い供試体5411の支持杭中央における 切断面（図-20）での圧縮軟化性状を示す. 図-25よ り，圧縮軟化したGauss pointは，載荷壁および支持 杭直近の要素に僅かに分布しているのみである。ま

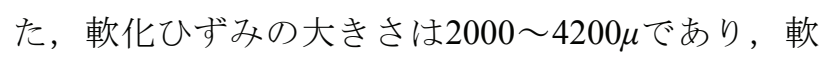
化の程度は小さい。このため, コンクリートの圧縮 軟化が押抜きせん断耐力に及ぼす影響は軽微であっ たものと考えられる。

\section{（2）曲げモーメントを受けるフーチングの押抜き せん断破壊性状}

RCスラブやフーチングの押抜きせん断耐力を評 価するには, いくつかの経験的な手法が提案されて いる。しかしこれらは, 単一荷重に対寸るものであ り, 多点荷重や, 面外力などが連成される場合など においては適用が困難であると考えられる，そこで, 本節では，水平および鉛直荷重によってスラブ載荷 面に圧縮力と曲げモーメントが作用寸る場合の押抜 きせん断破壊について, 解析の適用性を検証する.

a) 曲げモーメントを受けるフーチングの 押抜きせん断破壊実験

本検討で対象とした実験は, 土木研究所基礎研究 室で実施されたモーメントを受ける柱付きフーチン グの押抜きせん断実験の結果 ${ }^{15}$ である.

供試体寸法は, 図-26 に示すように 1900mm× $1900 \mathrm{~mm} \times 500 \mathrm{~mm}$ のフーチングに $500 \mathrm{~mm} \times 500 \mathrm{~mm} \times$ $1300 \mathrm{~mm}$ の載荷柱が施してある。フーチング部は, 有効高さ $(d)$ を $450 \mathrm{~mm}$, 支点から載荷柱縁端まで の距離を $450 \mathrm{~mm}$ とし， $\phi 220 \mathrm{~mm}$ の杭が 6 本（Case-

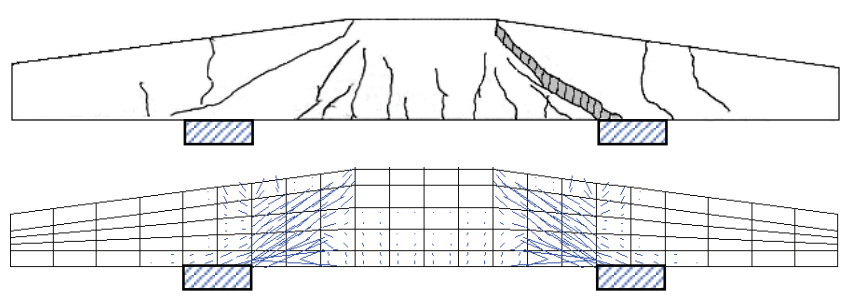

（1） 5405 のひび割れ性状

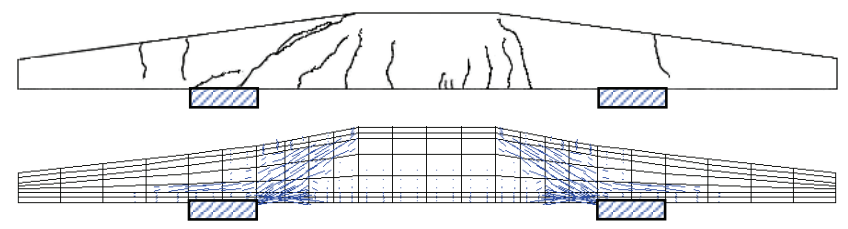

（2） 5406 のひび割れ性状

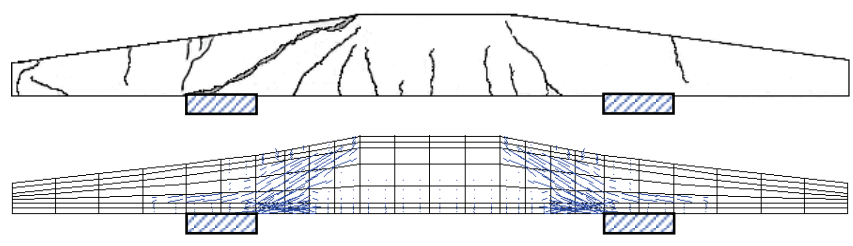

（3） 5408 のひび割れ性状
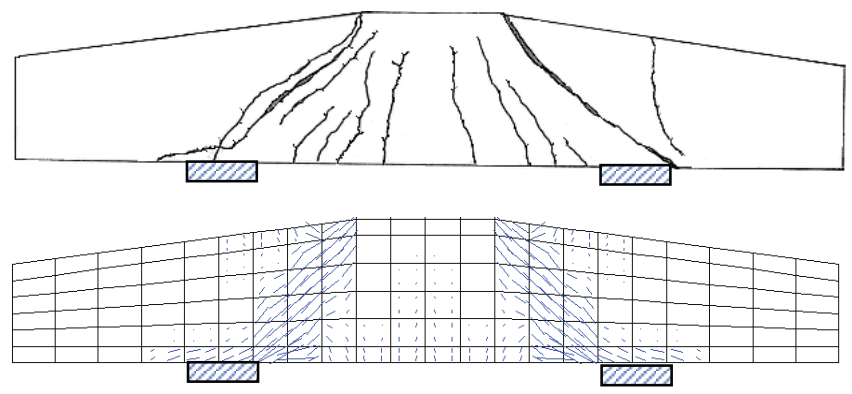

（4）5411のひび割れ性状

図ー24 フーチング側面でのひび割れ性状

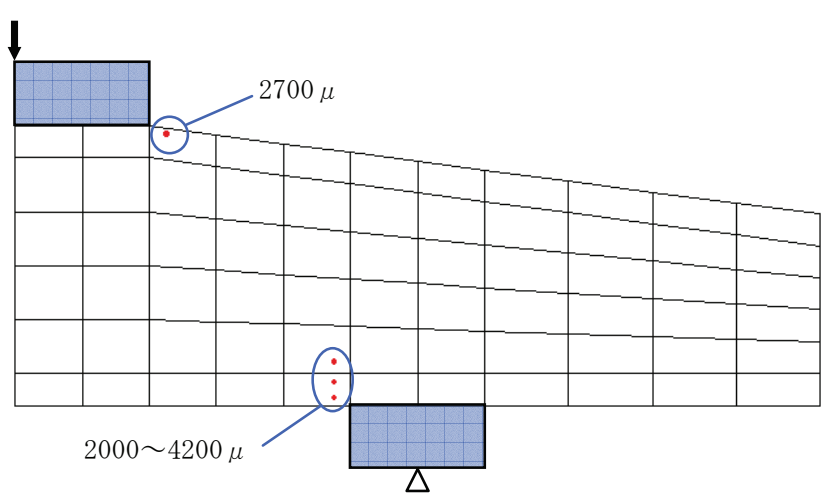

図ー25 フーチングの圧縮軟化性状

2-2）ないし8本（Case-2-4）設けられている．上側 および下側鉄筋には D19 が使用されており, ピッチ は両方向とも同一で，上側は $140 \mathrm{~mm}$ ，下側は $70 \mathrm{~mm}$ としてある、鉄笳の性質は, 降伏強度が $382 \mathrm{MPa}$, 剛性が $1.84 \times 10^{6} \mathrm{MPa}$ である。また, 載荷柱には, 軸方向にD32 のねじふし鉄筋を用い, 帯筋には D19 のフープ筋を使用してある.また, 柱の主鉄筋は, 
フーチングのみ込み部における定着長が不足するた め，供試体底面に定着板（アンカープレート）と定 着ナットを用いて固定されている。載荷方法は, 始 めに鉛直荷重を $1981 \mathrm{kN}$ 載荷し, その後鉛直荷重一 定のまま水平荷重を漸増させている.

\section{b) 解析モデル}

曲げモーメントを受けるフーチングの押抜きせん 断実験で使用した要素分割図を図-27に示す. 要素 分割は, $Y=0$ の面での $Y$ 方向の対称性を考慮した 1/2 モデルである. 実験では杭は円柱であるが，解 析では簡単のため, 杭と柱との純間隔が実験と等し くなるように， $220 \mathrm{~mm} \times 220 \mathrm{~mm}$ の矩形断面とし， $\mathrm{RC}$ 要素でモデル化した。境界条件は，支持位置に あたる節点すべてを 3 方向ともに拘束し，水平変位 は強制変位点を漸増変位させた，鉛直荷重は，柱部 の中心点に外力として作用させた.

\section{c） 実験結果と解析結果の検証}

曲げを受けるフーチングの実験および解析結果を 表-3に示す．杭を 8 本設けたCase2-2および， 6 本 設けたCase2-4 ともに解析值は実験值の $115,122 \%$ と なり若干耐力が大きくなる傾向であるが，概㸚評価 できている，図-28は，実験および解析での水平荷 重一水平変位関係を示す。荷重一変位関係に着目寸 ると，杭を 8 本設けたCase2-2では，実験は600kNあ たりから急激に剛性の低下が見られ，その後も緩や かに荷重が増加し最大荷重をむかえる，杭を 6 本設 けたCase2-4においても，450kNあたりから剛性の低 下が見られ，その後も緩やかに荷重は増加し最大荷 重に至る。解析でも $450 \mathrm{kN}$ 付近で岡性の低下が現れ ており, その後は実験ほどの低下傾向は現れなかっ たが, 荷重増加は徐々に緩やかになり, 最大荷重に 至る。このように解析における剛性低下は実験に比 べて小さいのではあるが, 定性的な傾向は一致して いる．解析では図-28の $\triangle$ 印の時点でフーチング部 に斜めひび割れが発生した後も荷重の増加が認めら れる.これはshear band部にアーチ型の耐荷機構が 形成されたものだと考えられる.

\section{d）破壊モードおよび破壊性状の検証}

ここで，実験および解析の破壞性状について着目 する．図-29は，ピーク荷重時のひび割れ性状を示 す。図-29より， shear band部に斜めひび割れが卓越 していることがわかる。 また, 図中の○印は，ピー ク荷重時に圧縮軟化したGauss pointを示寸。これら のGauss pointは載荷柱近傍の要素に数点存在してい る。また軟化を示すGauss pointのひず夕量は2000〜 $7500 \mu$ であり, 軟化の程度は大きくなく, 破壊は斜め ひび割れの発達によって導かれたものであると考え

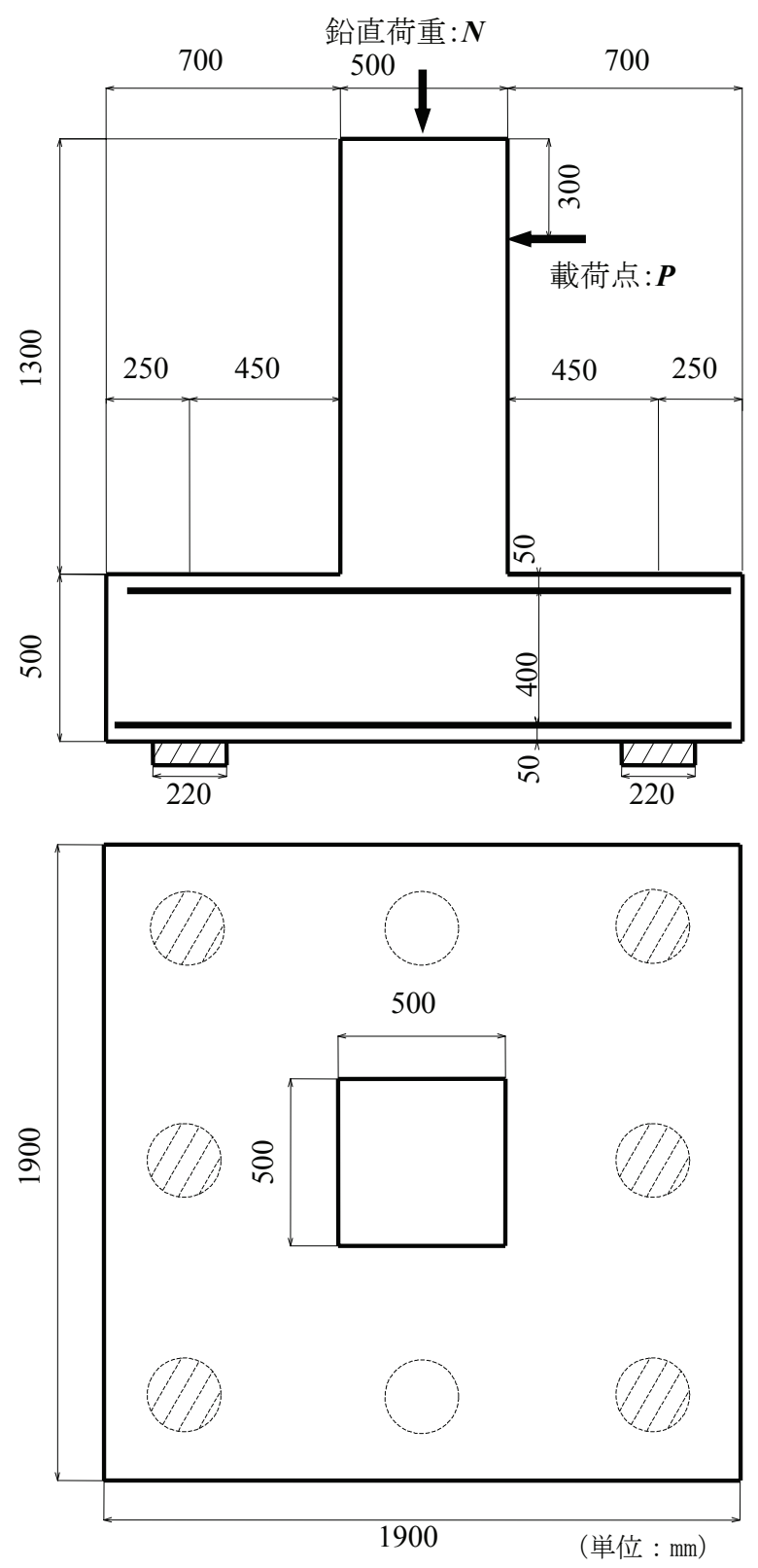

図ー26 曲げモーメントを受けるフーチングの供試体寸法

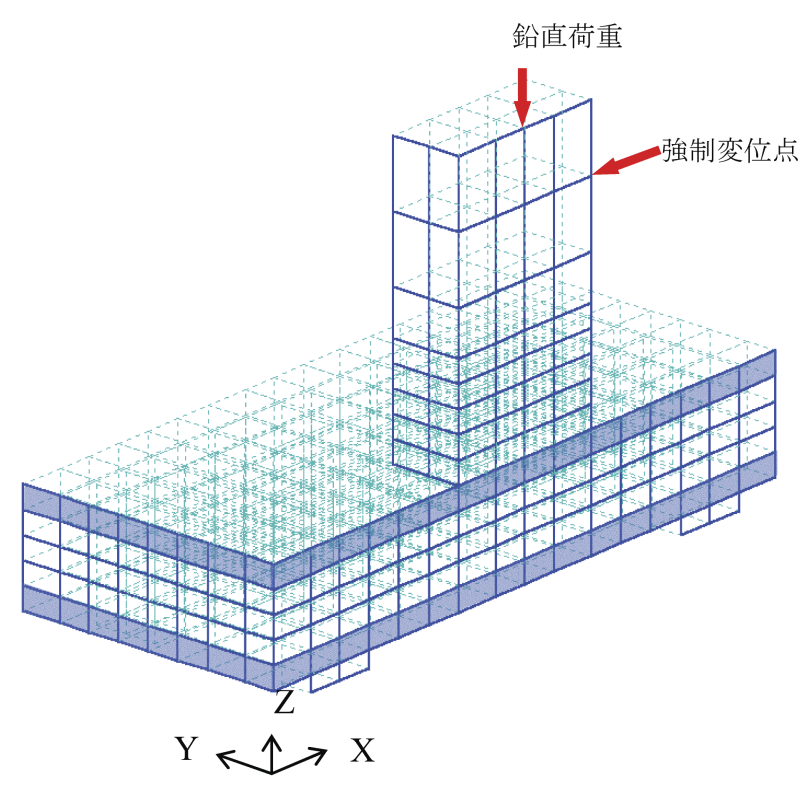

図-27 要素分割図 (対称 $1 / 2$ モデル) 
表ー3 曲げを受けるフーチングの実験・解析結果

\begin{tabular}{|c|c|c|c|c|c|}
\hline \multirow{2}{*}{ 供試体番号 } & \multirow{2}{*}{ 杭形式 } & \multirow{2}{*}{$\begin{array}{c}\text { コンクリート } \\
\text { 圧縮強度 }(\mathrm{MPa})\end{array}$} & \multicolumn{2}{|c|}{ 最大水平荷重 $(\mathrm{kN})$} & \multirow{2}{*}{ Pcal/Pe } \\
\cline { 4 - 5 } & & 実験值 : Pe & 解析值 : Pcal & \\
\hline Case2-2 & 8 本杭 & 29.3 & 863 & 994 & 1.15 \\
\hline Case2-4 & 6 本杭 & 28.5 & 800 & 977 & 1.22 \\
\hline
\end{tabular}

られる。

\section{5. 結論}

本研究では，スラブ状RC構造物の押抜きせん断 破壊に対して，著者らが開発した非線形三次元有限 要素法による解析を行い, 実験結果との比較によっ て解析の信頼性および妥当性を検討した.

薄いスラブの FEM 解析を行い, 以下のような結 論を得た.

(1) FEM 解析は剛性をやや大きく評価する傾向は あるが，載荷位置が自由縁および支点に近づく 場合の耐力および斜めひび割れ性状を精度よく 評価することができた.

(2) 薄いスラブの押抜きせん断破壊では，コンク リートの圧縮軟化の影響は小さく，本解析手法 によって挙動を評価できることが確認できた。 杭で支持された厚いスラブの FEM 解析を行い, 以下のような結論を得た。

(1) 厚いスラブで, せん断スパン比が小さい場合 の押抜きせん断破壊でも，圧縮軟化の影響は小 さく, FEM 解析によって押抜きせん断破壊性状 の評価が可能であると思われる.

(2) モーメントを受ける柱付きフーチングの押抜 きせん断破壊では，実験データが少ないため断 定はできないものの，FEM 解析によって評価が 可能であると思われる.

\section{参考文献}

1) Ozbolt, J. Mayer, U. and Vocke, H. : Smeared Fracture FE-Analysis of Reinforced Concrete Structures: Theory and Examples, Modeling of Inelastic Behavior of RC Structures under Seismic Loads, ASCE, pp.234-256, 2001.

2) 角田与史雄, 井藤昭夫, 藤田嘉夫 : 鉄筋コンクリー トスラブの押し抜きせん断耐力に関する実験的研究, 土木学会論文集，第229号 1974.9 .

3) 八若幹彦, 檜貝 勇, 中村 光, 斉藤成彦 : 3D-FEM によるRCスラブの押し抜きせん断性状の解析，構造 工学論文集, Vol.47A, 2001.4.

4) 八若幹彦: 有限要素法によるスラブ状RC構造物のせ 几断性状解析, 山梨大学修士論文, 2002.3.
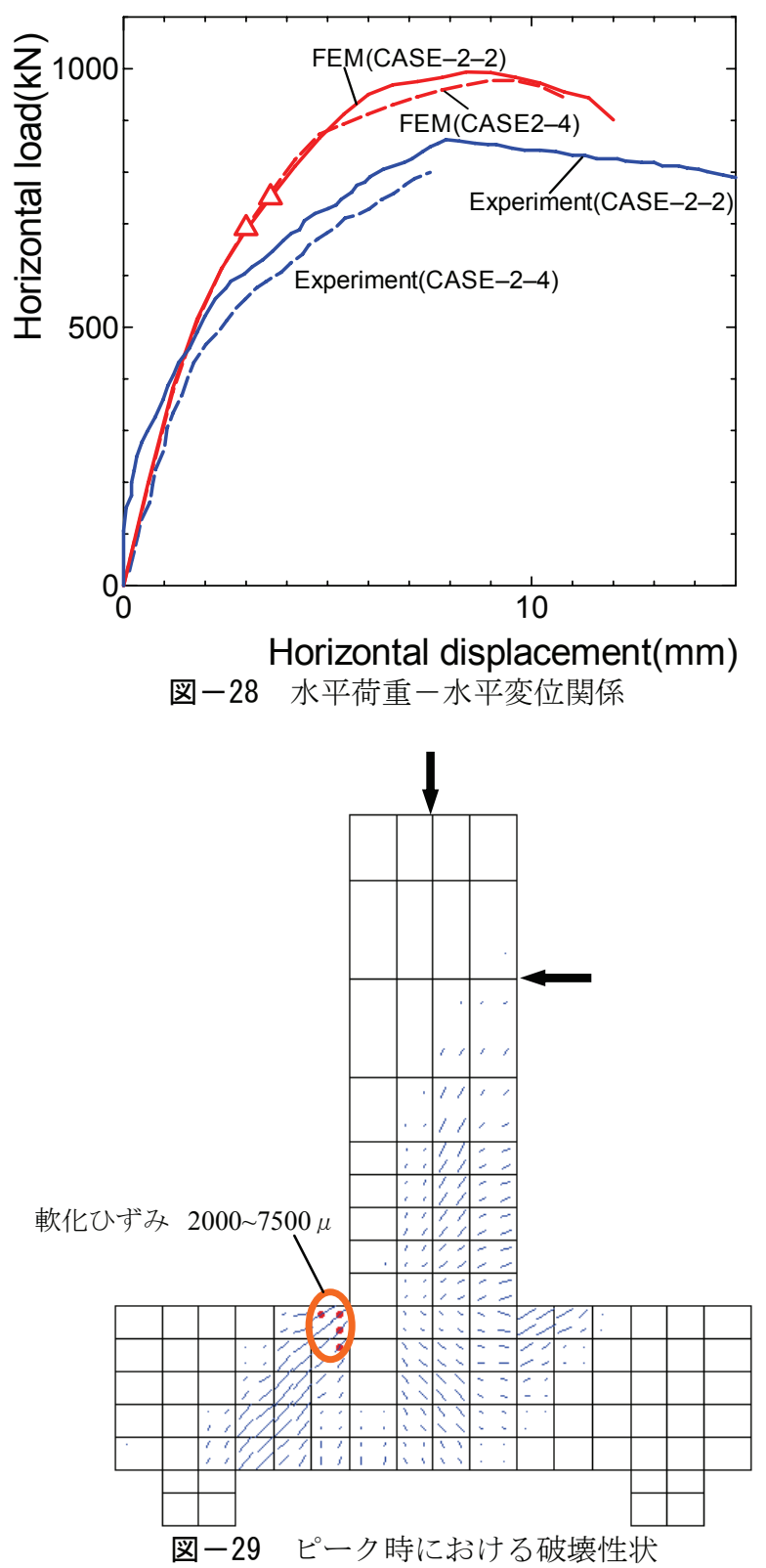

5) Nakamura, H. and Higai, T. :Compressive Fracture Energy and Fracture Zone Length of Concrete, Seminar on Postpeak Behavior of RC Structures Subjected to Seismic Loads, JCI, pp.259-272, 1990.

6) Collins, M. P. and Mitchell, D. :Prestressed Concrete Basics, Canadian Prestressed Concrete Institute, 1987.

7) 丁則平, 桧貝勇, 中村光 : 有限要素法による $\mathrm{RC}$ 部材 のせん断破壊性状の検討, コンクリート工学年次論 文報告集，Vol.19, No.2, 1997 . 
8) 山谷 敦 : 有限要素法による $\mathrm{RC}$ 部材のせん断挙動に 関する研究, 山梨大学博士論文, 2000.12 .

9) 井上寛規, 檜貝勇, 中村光 : RC部材におけるせん断 補強鉄筋の効果，コンクリート工学年次論文集， Vol.21, No.3,1999.

10）飯塚敬一, 中村光, 足立正信, 檜貝勇 : 不連続回転 ひび割れモデルによるRC梁の有限要素法解析, コン クリート工学年次論文報告集, Vol.19, No.2, 1997.

11）山田一宇，青柳征夫：ひびわれ面におけるせん断伝 達, 第2回RC構造のせん断問題に対する解析的研究 に関するコロキウム論文集，pp.19-28，1983.10.

12）前田幸雄，松井繁之：鉄筋コンクリート床板の押抜 きせん断耐力の評価式，土木学会論文集，第348号 /V-1, 1984.8.
13) コンクリート標準示方書 構造性能照査編〔2002年 制定]，土木学会

14）石橋忠良, 松田好史, 斉藤啓一：少数本のくいを用 いたフーチングのせん断設計について, 土木学会論 文報告集，第337号，1983.9.

15) 建設省土木研究所構造橋梁部基礎研究室, フーチン グの設計および補強方法に関する実験的研究，土木 研究所資料, 第3550号, 1998.3 .

(2006. 5. 30受付)

\section{ANALYSIS OF PUNCHING SHEAR FAILURE OF RC SLABS USING NON- LINEAR FINITE ELEMENT METHOD}

\section{Mikihiko YAWAKA, Takeshi HIGAI, Hikaru NAKAMURA and Shigehiko SAITO}

The applicability of 3D non-linear FEM, which has been developed by the authors, on the punching shear failure of RC slabs was studied.

In this paper, experimental results of thin RC slabs, subjected to a concentrated load at various position, and relatively thick RC slabs, loaded through walls or columms connected on the slabs, were compaired with the analytical results using the FEM program.

It was shown that authors' FEM analysis are able to well estimate the punching shear failure of RC slabs, interms of shear strength, diagonal cracking pattern and load-deflection relation. 